\title{
Regulation of autoreactive $B$ cells during innate immune responses
}

\section{Jennifer Ann Rutan}

A dissertation submitted to the faculty of the University of North Carolina at Chapel Hill in partial fulfillment of the requirements for the degree of Doctor of Philosophy in the Department of Microbiology and Immunology

Chapel Hill

2008

Approved by:

Barbara J. Vilen, Ph.D.

Stephen H. Clarke, Ph.D.

Jeffrey A. Frelinger, Ph.D.

Larry W. Arnold, Ph.D.

Jenny P. Y. Ting, Ph.D. 
(C) 2008

Jennifer Ann Rutan

ALL RIGHTS RESERVED 


\begin{abstract}
Jennifer Ann Rutan: Regulation of autoreactive B cells during innate immune responses (Under the direction of Dr. Barbara J. Vilen)
\end{abstract}

A diverse repertoire of $\mathrm{B}$ cell specificities is critical to combat pathogenic threats, but this diversity is tinged with the threat of autoimmunity. Autoimmune diseases such as systemic lupus erythematosus (SLE) underscore the need for strict regulation of B cell activation during immune responses. Regulation of the adaptive immune response is dependent on B cell receptor (BCR) ligation, affinity of the BCR-antigen interaction, and the presence of costimulatory molecules. Mechanisms of central tolerance and peripheral tolerance eradicate B cells that inappropriately bind self-antigens. Autoreactive B cells that escape these mechanisms of tolerance and encounter antigen in the absence of costimulatory signals enter an unresponsive state known as anergy. Anergic B cells do not differentiate into plasma cells, activate transcription factors such as Blimp-1 and XBP-1, or secrete immunoglobulin (Ig). B cells can also be activated by toll-like receptor (TLR) ligands and contribute to the innate immune response, the first line of defense against pathogens. Bacterial and viral components are the archetypical TLR ligands, but endogenous DNA and RNA can also bind TLRs and activate the innate immune system. Therefore, it is critical to regulate the innate immune response to prevent autoimmunity, and this regulation requires unique mechanisms that are not necessarily dependent on BCR ligation. Ideally, these mechanisms would also 
discriminate between naïve and chronically antigen-experienced B cells, allowing naïve B cells to respond to threats while potentially autoreactive B cells remain quiescent. We have recently described a mechanism where antigen-experienced B cells are regulated by IL-6 and sCD40L released by dendritic cells (DCs) and macrophages (MФs) during innate immune responses. Naïve B cells are unaffected by these factors, permitting a robust immune response in the absence of autoimmunity. IL-6/sCD40L-mediated repression is dependent on ERK activation and "repressed" antigen-experienced cells exhibit a decrease in activated ERK in the nucleus. Identifying new targets for SLE therapies could enable specific regulation of antigen-experienced B cells instead of nonspecific B cell depletion and immunosuppression. 
To Mom and Dad, Andy, and Zach,

with gratitude for their unending love, support, and patience.

To Annie, Bullet, Jack, Star, and Fancy, for their comfort and undying loyalty.

I love you all. 


\section{ACKNOWLEDGEMENTS}

I would like to thank my advisor, Dr. Barbara Vilen, for the training she has provided in the practice of science, critical analysis of data, writing of manuscripts, and management of a laboratory and its members. I have learned a great deal from my time in her laboratory, and I appreciate the additional writing and editing opportunities that she provided. I am also grateful to my other graduate school mentors, particularly the members of my thesis committee, Drs. Steve Clarke, Jeff Frelinger, Larry Arnold, and Jenny Ting, as well as Dr. Zhi Liu. I would also like to thank the past and present members of the Vilen Lab for their scientific and moral support as well as their friendship, especially Heather Mueller Rauscher, Jin Kim, Mileka Gilbert, Diane Carnathan, Michelle Kilmon, Bianca Trollinger, Nikki Wagner, Stephanie CarmicleDavis, Shannon Jones, and Sang-Ryul Lee. You have all taught me about the importance of good life choices.

My family has always supported me in my educational pursuits, and I would like to thank them for their love and encouragement. In particular, I would like to thank my parents for their sacrifices, my brother for his optimism and humor, my grandparents for their unconditional faith in me, and Uncle Joe for being my scientific role model (and giving me my first microscope!). I love you all.

Finally, I owe an extreme debt of gratitude to my husband, Zach. He has suffered through late-night emergency rides home, a lack of housekeeping and cooking, and all the other occupational hazards of living with a graduate student. He has been a 
wonderful partner in life and in raising puppies. Without his love and support, I would be lost. I also have to acknowledge our loving dogs, past and present, especially Annie, Bullet, Jack, Star, and Fancy, Winnie, Katie, KC, and all of Annie's puppies, for the comfort, unconditional love, loyalty, and comic relief they have given to us. Happiness is truly a warm puppy, and they have provided us with a great deal of happiness over the years. I love you all. 


\section{TABLE OF CONTENTS}

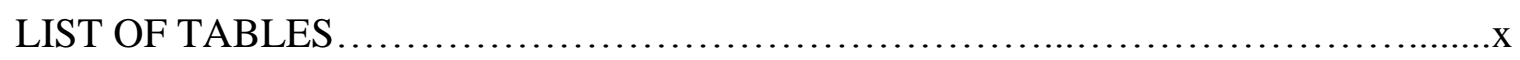

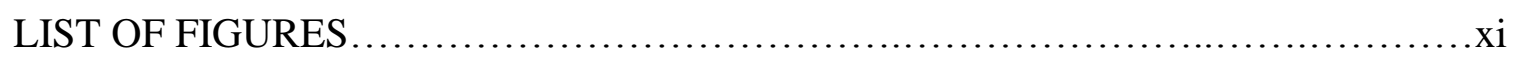

LIST OF ABBREVIATIONS AND SYMBOLS.....................................xii

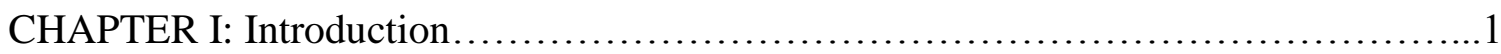

1.1. Learning tolerance: a B cell's story .....................................

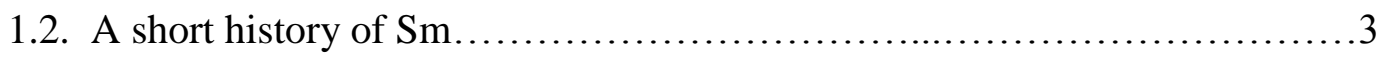

1.3. Arresting and silencing Sm-specific B cells.............................5

1.4. Failed tolerance: Sm-specific autoantibodies in a murine model of SLE.......9

1.5. Apoptotic cells: dangerous in death.................................... 11

1.6. Selective repression: new treatments for SLE?...........................................14

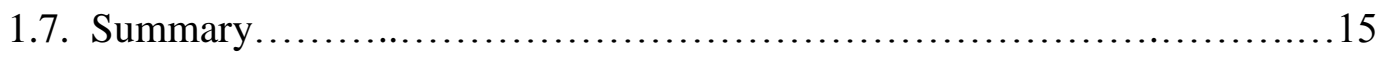

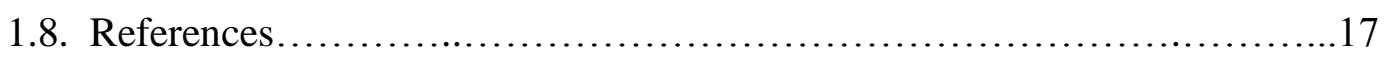

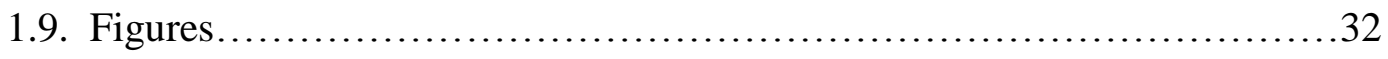

CHAPTER II: ERK prevents differentiation of autoreactive B cells during innate immune responses.................................. 33

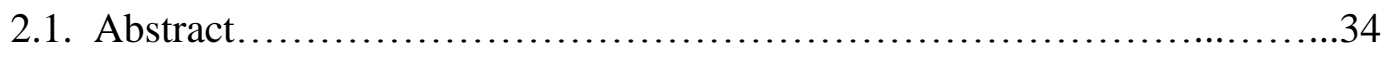

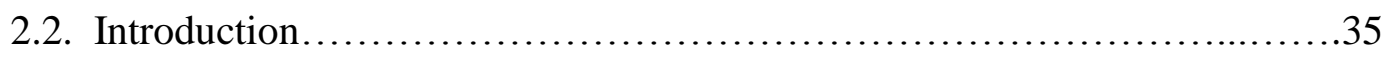

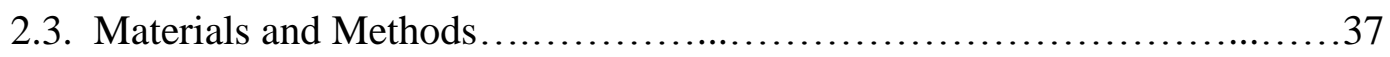


2.5. Results.

2.5. Discussion........................................................ 48

2.6. References.................................................52

2.7. Figures....................................................... 57

CHAPTER III: Discussion.................................................63 


\section{LIST OF TABLES}

Table 2.1. Real-time PCR primers and their sequences..........................41 


\section{LIST OF FIGURES}

Figure 1.1. DCs and MФs repress antibody secretion from autoreactive B cells via IL- 6 and sCD40L

Figure 2.1. IL-6 and sCD40L selectively repress Ig secretion by chronically antigen-experienced B cells

Figure 2.2. IL-6 and sCD40L treatment causes a decrease in levels of transcription factors involved in plasma cell differentiation.

Figure 2.3. IL-6- and sCD40L-mediated repression is dependent on Erk activation

Figure 2.4. Chronically antigen-experienced $2-12 \mathrm{H} / \mathrm{V} \kappa 8 \mathrm{~B}$ cells exhibit

higher basal phosphorylation of Erk than naïve C57BL/6 B cells

Figure 2.5. IL-6 and sCD40L alter the subcellular localization of

activated ERK in chronically antigen-experienced B cells... 


\section{LIST OF ABBREVIATIONS AND SYMBOLS}

\begin{tabular}{|c|c|}
\hline BCR & B cell receptor \\
\hline BLIMP-1 & B lymphocyte induced maturation protein 1 \\
\hline BLyS & B lymphocyte stimulator \\
\hline BMT & nonmyeloablative bone marrow transplant \\
\hline $\mathrm{DC}$ & dendritic cell \\
\hline dsDNA & double-stranded DNA \\
\hline DTT & dithiothreitol \\
\hline ERK & extracellular signal-related kinase \\
\hline FcR & Fc receptor \\
\hline FO & follicular \\
\hline HEL & hen egg lysozyme \\
\hline HSCT & nonmyeloablative hematopoietic stem cell transplant \\
\hline IC & immune complex \\
\hline Ig & immunoglobulin \\
\hline IL-4 & interleukin-4 \\
\hline IL-6 & interleukin-6 \\
\hline IL-6R & interleukin-6 receptor (CD126) \\
\hline KSR & kinase suppressor of Ras \\
\hline LPS & lipopolysaccharide \\
\hline MAPK & mitogen-activated protein kinase \\
\hline MEF & mouse embryonic fibroblast \\
\hline mRNA & messenger RNA \\
\hline
\end{tabular}




\begin{tabular}{|c|c|}
\hline $\mathrm{M} \Phi$ & macrophage \\
\hline $\mathrm{MZ}$ & marginal zone \\
\hline NES & nuclear export signal \\
\hline NLS & nuclear localization signal \\
\hline PAMP & pathogen-associated molecular pattern \\
\hline PI3-K & phosphatidylinositol 3-kinase \\
\hline PMSF & phenylmethanesulfonyl fluoride \\
\hline $\mathrm{RF}$ & rheumatoid factor \\
\hline $\mathrm{sCD} 40 \mathrm{~L}$ & soluble CD40L \\
\hline SLE & systemic lupus erythematosus \\
\hline $\mathrm{Sm}$ & Smith antigen \\
\hline snRNA & small nuclear RNA \\
\hline snRNP & small nuclear ribonucleoproteins \\
\hline ssRNA & single-stranded RNA \\
\hline $\mathrm{Tg}$ & transgenic \\
\hline TLR & Toll-like receptor \\
\hline XBP-1 & X-box protein 1 \\
\hline
\end{tabular}




\section{CHAPTER I}

\section{Introduction}

This review was originally published in Immunologic Research.

Vilen, B.J., and Rutan, J.A.

The regulation of autoreactive $\mathrm{B}$ cells during innate immune responses.

Immunologic Research. 2008;41(3):295-309

(C) Springer Science+Business Media, LLC 2008 


\subsection{Learning tolerance: a B cell's story}

A diverse B cell repertoire is critical in combating pathogens, but inherent in generating diversity is the threat of autoimmunity. In the bone marrow, central tolerance mechanisms such as deletion or receptor editing remove high affinity autoreactive B cells before they exit to the periphery (1-10). Those that escape are subject to receptor revision $(8,11-14)$, peripheral deletion $(15,16)$, or a shortened lifespan because they fail to enter B cell follicles (17-22). In rare cases, autoreactive B cells are fully functional but indifferent to their specific antigen (23-25). Finally, many low affinity autoreactive B cells are maintained in an unresponsive state known as anergy. Anergic B cells do not receive sufficient activation signals to differentiate into plasma cells or secrete immunoglobulin (Ig) in response to antigenic or mitogenic stimulation (26-29). Their proliferative responses to $\mathrm{B}$ cell receptor (BCR) or toll-like receptor (TLR) signaling as well as their lifespans vary in different models $(18,30-35)$. Some anergic B cells transduce BCR-derived signals (30, 32, 36-40), while others exhibit desensitized BCRs $(30,33,41)$. Quiescence is dependent on chronic exposure to self-antigen and occupancy of the $\operatorname{BCR}(42,43)$. Furthermore, ERK activation is critical in sustaining anergy during polyclonal stimulation by TLR ligands $(27,28)$. Recently, it was demonstrated that anergy can be mediated by DCs and MФs. In the presence of TLR ligands, DCs and MФs release IL-6 and sCD40L that selectively represses Ig secretion from autoreactive B cells $(44,45)$. In the absence of DCs/MФs and their soluble factors, autoreactive B cells regain the ability to secrete $\mathrm{Ig}$, indicating that this mechanism of tolerance is reversible. These data suggest that autoreactive B cells must be maintained in close proximity to DCs/MФs during innate immune responses to prevent autoimmunity. 
The affinity and avidity of the antigen-BCR interaction determines whether developing B cells will be deleted, edited, anergized, or ignored (46). Self-reactive B cells that survive these developmental checkpoints tend to bind self-antigens with low affinity and they remain anergic in the absence of costimulation by cognate $\mathrm{T}$ cells. Many of the early transgenic (Tg) models expressed BCRs with high affinities. However, concerns were raised that these models may not adequately reflect how bona fide low affinity self-antigens are regulated $(1,26)$. To study the tolerance mechanisms regulating low-affinity B cells, new Ig Tg models were generated that expressed BCRs specific for double-stranded (ds) DNA, single-stranded (ss) DNA, rheumatoid factor $(\mathrm{RF})$, insulin, and Smith antigen (Sm).

\subsection{A short history of Sm}

Sm antigens are conserved proteins that are indispensable in RNA splicing. In 1966, Sm was identified as a unique autoantigen, the first non-histone target of autoantibodies in systemic lupus erythematosus (SLE) patients (47). Named for 15-yearold Stephanie Smith, antibodies to Sm became one of the diagnostic criteria for SLE (48), detectable in 5-30\% of SLE patients $(48,49)$. Later studies correlated anti-Sm titers with kidney disease (50-53).

The autoantibodies isolated from patient sera proved invaluable in the initial studies of the Sm proteins (54). The small nuclear RNA (snRNA U1, U2, U4, or U5) in each small nuclear ribonucleic particle (snRNP) is predicted to thread through the center of a heptameric ring of Sm proteins (E, F, G, D1, D2, D3, and B/B') (55). Three of the Sm proteins (D1, B, and D3) have long, positively charged tails that contact the pre- 
mRNA in the 5' splice site region (56). This interaction stabilizes the commitment complex formed when $\mathrm{U} 1 \mathrm{snRNP}$ binds the pre-mRNA substrate (57). The remaining snRNPs, $\mathrm{U} 2$ and $\mathrm{U} 4 / \mathrm{U} 5 / \mathrm{U} 6$ (the triple snRNP) bind to pre-mRNA, rearrange to form the splicesome, and remove introns from the transcript (58).

Self-antigens composed of protein and DNA or RNA can co-ligate the BCR with TLRs, potentially overcoming tolerance mechanisms and activating autoreactive B cells. For example, concomitant ligation of the BCR and TLR9 by chromatin:IgG immune complexes activates RF-specific B cells in the absence of T cell help or overt TLR stimulation $(38,59,60)$. Signaling through both the BCR and TLR9 is necessary to activate NF- $\mathrm{kB}$ in these B cells (37). Recently, RNA-IgG immune complexes were shown to activate RF-specific B cells via TLR7 (39). TLR7 binds ssRNA, a viral antigen that acts as a sensor of infection as well as a component of the U1 snRNP splicing complex, a known autoantigen in SLE $(61,62)$. Aberrantly high expression of TLR7, or an increased burden of immune complexes and/or apoptotic cells, aggravates disease in lupus-prone mice. For instance, the gene duplication of TLR7 in Yaa mice results in hyperactive B cells, exacerbation of disease in lupus-prone models, and shifts autoantibody specificities to RNA $(63,64)$. Reducing TLR7 gene expression ameliorates disease and increases survival (63). Hence, the combination of self-proteins and TLR ligands within immune complexes and on the surface of apoptotic cells can mistakenly activate autoreactive B cells and result in autoimmunity. 


\subsection{Arresting and silencing Sm-specific B cells}

Sm-specific autoantibodies are a hallmark of both human and murine lupus. To identify the mechanisms that regulate Sm-specific B cells, the $2-12 \mathrm{H} \mathrm{Tg}$ mice were generated $(35,65)$. In this model, an Ig heavy chain, 2-12H, was identified from an Smspecific hybridoma derived from an MRL/lpr mouse. The $2-12 \mathrm{H}$ chain pairs with a variety of light chains, giving rise to B cells specific for Sm and/or ss-DNA. B cells from the $2-12 \mathrm{H}$ model express BCRs of multiple affinities that develop and are regulated on a non-autoimmune background.

Tolerance to $\mathrm{Sm}$ is dependent on several cell types. B cells are the most obvious suspects in SLE since disease pathology is mediated by autoantibodies. In vivo, Smspecific B cells are regulated since $2-12 \mathrm{H}$ Tg mice have low titers of anti-Sm antibodies $(35,66)$. However, ex vivo non-subsetted 2-12H B cells (uncontaminated by DCs and MФs) are activated by TLR stimulation (LPS, CpG, dsRNA) in vitro but their Ig secretion is lower than that of C57BL/6 controls $(35,67)$. The follicular (FO) B cell subset is repressed by DCs and MФs secreting IL-6 and sCD40L, while secretion by the MZ B cell subset is partially repressed, but only by MФs and SCD40L (45). Some MZ B cells and peritoneal B-1 cells ignore endogenous levels of Sm, but an increase in the number of apoptotic cells can activate peritoneal and MZ B cells $(66,68,69)$. Smspecific B cells arrested at the pre-plasma cell stage, interrupting plasma cell differentiation and preventing Ig secretion (32)

Restricting the light chain that pairs with $2-12 \mathrm{H}$ allowed for the analysis of Smspecific B cells of moderate and low affinity $(32,70)$. The $2-12 \mathrm{H} / \mathrm{V} \kappa 4 \mathrm{Tg}$ mouse was generated to examine regulation of higher affinity anti-Sm responses (70). B cells from 
this mouse are distributed among splenic transitional, FO, and MZ subsets, as well as the peritoneal B-1 subset (70). 2-12H/Vк4 B cells are anergic and all subsets are hyporesponsive to LPS in vitro. Additionally, MZ B cells exhibit a block in BCR signaling (70). LPS-stimulated 2-12H/Vк4 B cells are repressed by IL-6 and sCD40L (unpublished data). To study low-affinity anti-Sm responses, the 2-12H/Vк8 Tg mouse was created (32). In this model, only transitional and FO B cells are present and these cells are regulated by anergy (32). As in the previous anti-Sm models, 2-12H/Vк8 B cells are susceptible to IL-6- and sCD40L-mediated repression $(44,45)$.

$\mathrm{T}$ cells are implicated in SLE and Sm-specific T cells are present in the repertoires of both normal and autoimmune mice (71). Sm-specific T cells in $2-12 \mathrm{H} \mathrm{Tg}$ mice are anergic and do not proliferate in response to B cells presenting Sm (71). Anergic T cells are also unable to upregulate $\mathrm{CD} 40 \mathrm{~L}$ and provide costimulation to their cognate $\mathrm{B}$ cells (72). Anti-Sm B cells do not secrete Ig in vivo $(35,65)$, perhaps because they are deprived of $\mathrm{T}$ cell costimulation. However, in autoimmune situations, autoreactive $\mathrm{T}$ cells induce class-switching and somatic hypermutation of anti-Sm B cells, resulting in high levels of pathogenic high-affinity $\operatorname{IgG}$ autoantibodies $(73,74)$. Paradoxically, antiSm B cells are required to tolerize Sm-specific T cells from C57BL/6 mice, but they activate Sm-specific T cells from MRL/lpr mice $(71,75,76)$. This indicates that although $\mathrm{T}$ cells are necessary for the development of autoantibodies and disease, they are also regulated by autoreactive B cells in normal individuals.

DCs and MФs regulate innate and adaptive immune responses by tolerizing or activating $\mathrm{T}$ and $\mathrm{B}$ cells. The continued ingestion and presentation of self-antigens or the acute presentation of foreign antigen by $\mathrm{DCs} / \mathrm{M} \Phi$ s either tolerizes or activates $\mathrm{T}$ cells to 
drive adaptive immune response. The activation of DCs during innate immune responses induces the secretion of IL- 6 that promotes immunity by releasing CD $4^{+}$T-helper cells from their inhibitory functions (77). This promotes polyclonal activation of naive B cells, the production of neutralizing antibody and the clearance of the invading pathogen.

In addition to regulating T cells, DCs and MФs affect the fate of B cells. They activate naïve B cells by secreting type I interferon, IL-6, and B lymphocyte stimulator (BLyS) (78-80). They also repress Ig secretion by B cells that have been chronically exposed to antigen. Our laboratory showed that DCs and MФs regulate autoantibody production, in part through their secretion of IL-6 and sCD40L $(44,45)$. Repression is selective in that naïve B cells (not chronically exposed to antigen) are unaffected by the presence of IL-6 and sCD40L while Ig secretion by autoreactive B cells is repressed (Figure 1A). Coupled with the data showing that IL-6 de-represses regulatory T cells, a mechanism emerges explaining how the pleiotropic affects of IL-6 produced by DCs and MФs simultaneously promotes immunity and represses autoimmunity during innate immune responses.

Signal transduction through many cell surface receptors influences neighboring receptors. For example, crosstalk between the IFN- $\alpha \beta$ and IL-6 receptor (IL-6R) signaling pathways augment transcription factor binding and gene expression in mouse embryonic fibroblasts (MEFs) (81). Similarly, stimulation of B cells with sCD40L, IL-4, and LPS reprograms the BCR signaling pathway, enhancing ERK activation and bypassing the requirement for phosphatidylinositol 3-kinase (PI3-K) (82-86). The findings that only B cells chronically exposed to self-antigen are susceptible to repression by IL-6 and sCD40L suggests that chronic BCR-derived signals "reprogram" the 
outcome of IL-6R and CD40 signal transduction. On a molecular level, the ability of IL6 and sCD40L to repress Ig secretion reflects diminished BLIMP-1 and XBP-1 mRNA and protein levels. These data indicate that regulation occurs upstream of transcriptional activation. In support of this, pharmacologically inhibiting MEK restores LPS-induced Ig secretion. This suggests that the ability of IL-6/sCD40L to repress TLR4-induced Ig secretion is MEK/ERK-dependent (unpublished data).

Susceptibility of B cells to IL-6/sCD40L requires that B cells be chronically exposed to antigen, consistent with a central role for the BCR in tolerance. High affinity neo-self-antigens direct a unique tolerance scheme compared to low-affinity selfantigens. Anergic B cells from high affinity models are characterized by elevated phospho-ERK $(42,87)$. In addition, the binding of high affinity antigen to the BCR and constitutive MEK/ERK activation is sufficient to repress TLR4 and TLR9-induced Ig secretion $(27,28)$. In the low affinity Sm model $(2-12 \mathrm{H} / \mathrm{V} \kappa 8)$ basal phospho-ERK levels are comparable to those in the HEL model. However, unlike the HEL model, the binding of soluble SmD or snRNPs coupled with elevated phospho-ERK levels does not repress TLR-induced Ig secretion (unpublished data). This indicates that ERK is only part of the "BCR-derived" signals that regulate innate immune responses in vivo. Although B cells expressing high affinity receptors can be repressed by IL-6 and SCD40L, antigen stimulation is sufficient. In contrast, B cells expressing low affinity receptors for bona fide self-antigens (Sm and ssDNA) do not achieve sufficient BCR-derived signals to influence TLR4-induced Ig secretion and depend on additional signals from IL6/sCD40L (unpublished data). 
The finding that DCs secrete IL-6 while MФs secrete IL-6 and sCD40L suggests that the anatomical location within the secondary lymphoid organs might dictate how autoreactive B cells are regulated. Marginal zone B cells are solely repressed by SCD40L while FO B cells are repressed by IL-6 and sCD40L (45). This specificity may result from the anatomic location, since different subsets of DCs and МФs localize to specific regions of the spleen. For example, B cells are retained in the marginal zone by МФs (88) and they are regulated by M $\Phi$-derived SCD40L. However, upon activation and differentiation into pre-plasma cells, they may become susceptible to repression by IL-6 secreted by DCs within the periarteriolar lymphoid sheath (PALS). Thus, depending on the anatomical location of the autoreactive B cell, DCs and/or MФs can repress autoantibody production during innate immune responses.

\subsection{Failed tolerance: Sm-specific autoantibodies in a murine model of SLE}

MRL/lpr mice are a well-characterized murine model of SLE, with adult-onset disease mediated by autoantibody deposition and tissue destruction. The prevalence of anti-Sm autoantibodies in human SLE patients and MRL/lpr mice is approximately 25\% $(89,90)$. BCR Tg models have been bred onto the MRL background, allowing B cells of known specificities to be followed throughout development. Developmental arrest, follicular exclusion, and receptor editing are defective in MRL/lpr mice $(91,92)$. Expression of the 2-12H transgene in MRL/lpr mice increases the prevalence of the antiSm response, accelerates disease, and leads to higher serum anti-Sm levels (65). Smspecific B cells from 2-12H mice are arrested at the pre-plasma cell stage, while B cells from the 2-12H/MRL/lpr mice bypass this checkpoint and become activated (93). 
The presence of class-switched autoantibodies in MRL/lpr mice suggests a breakdown in tolerance within the adaptive immune response. In MRL/lpr mice where somatic hypermutation and isotype switch recombination are blocked $\left(\mathrm{AID}^{-/}\right)$, lupus-like symptoms such as glomerulonephritis, proteinuria, and immune complex deposition are ameliorated (94). Early studies showed a critical role for T cells in disease because thymectomized MRL/lpr mice failed to develop lupus-like disease (95). Subsequently, it was shown that defects in central deletion and the number and function of T-regulatory cells allow $\mathrm{CD}^{+}{ }^{+} \mathrm{T}$-helper cells to activate autoreactive $\mathrm{B}$ cells, induce terminal differentiation and autoantibody production (96-101).

Dysregulation of the innate immune system is apparent in MRL/lpr mice (39). Immune complexes containing RNA or chromatin stimulate RF-specific B cells through TLR7 and TLR9 to secrete anti-Sm and anti-chromatin $(38,39)$. Consistent with a role for TLRs, autoantibody responses were reduced in $\mathrm{MyD} 88^{-/} / \mathrm{MRL} / \mathrm{lpr}$ mice (39) and disease was ameliorated (102). $\mathrm{TLR}^{-1 /} / \mathrm{MRL} / \mathrm{lpr}$ mice exhibit reduced autoantibody titer and gene duplication of TLR7 shifts autoantibody specificities toward RNA, exacerbating disease $(63,64)$. This reveals TLR7 as a key receptor in promoting autoimmunity when tolerance is overcome $(63,103)$. Like TLR $7^{-/-}$mice, $\mathrm{TLR} 9^{-/} / \mathrm{MRL} / \mathrm{lp} r$ mice exhibited lower titers of anti-DNA autoantibodies. However unlike TLR $7^{-1-}$ mice, they remain plagued by accelerated kidney disease and increased mortality (103). These data suggest that TLR9 induces anti-DNA responses but also has an anti-inflammatory effect, possibly through its induction of regulatory $\mathrm{T}$ cells $(104,105)$. The function of regulatory $\mathrm{T}$ cells in $\mathrm{TLR}^{-/ /} / \mathrm{MRL} / \mathrm{lpr}$ mice is impaired, potentially allowing autoreactive cells to exacerbate disease (106). These data indicate that innate immune responses have 
tremendous and opposing effects on autoantibody production and disease in MRL/lpr mice.

Defects in DC/MФ-mediated tolerance are evident in lupus-prone mice. Our studies indicate that secretion of IL-6 and sCD40L by DCs/M $\Phi$ s, as well as reprogramming of IL-6R and CD40 in autoreactive B cells, promote tolerance during innate immune responses. This implies that defects in either the secretion of IL6/sCD40L or the selective response of autoreactive B cells to these factors regulate autoantibody production. Our studies indicate that DCs and MФs from MRL/lpr mice are unable to repress autoreactive B cells (Figure 1B). Defects in DC/MФ-mediated repression are coincident with diminished secretion of IL-6 and SCD40L and failure to

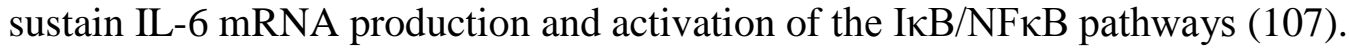
Similarly, we found that IL-6 and sCD40L fail to repress B cells from lupus-prone mice (unpublished data). The finding that lupus-prone mice harbor defects in DCs/MФs and B cells suggests the influence of an environmental stimulus.

\subsection{Apoptotic cells: dangerous in death}

Apoptotic cells pose a unique challenge to the immune system since they are a rich source of nuclear antigens, including DNA, immune complexes, nucleosomes, histones, snRNPs and snRNAs, Ro, La, and Sm. These self-antigens can be modified by phosphorylation and/or alternate protein cleavage, revealing novel epitopes that were not available during the induction of B and T cell tolerance (108-111). During cell death, self-antigens are distributed in large and small blebs on the cell surface and act as targets for autoreactive B cells in a membrane-bound, multimeric form (112-114). The display 
of self-antigens on apoptotic cells is necessary to develop autoantibodies. For instance, autoantibodies to cytoplasmic but not nuclear antigens develop when nuclear fragmentation is blocked in apoptotic cells (115). Therefore, it is imperative that scavenger cells such as MФs and DCs quickly clear apoptotic cells and their associated self-antigens to minimize inflammatory and autoimmune responses.

Apoptotic cells are bound and cleared by a variety of receptors on DCs and MФs. Ingestion of apoptotic cells reduces the secretion of proinflammatory cytokines by DCs and MФs, inhibiting their maturation and controlling the activation of $\mathrm{T}$ cells and autoimmune responses to apoptotic cells (116-121). Decreased clearance of apoptotic cells and defects in phagocytosis by MФs in SLE patients and lupus-prone mice may lead to autoimmunity $(69,108,122-124)$. The increase in apoptotic cells and antigens could dysregulate DCs and MФs, triggering a chronic anti-inflammatory response that downregulates the production of cytokines important for B cell tolerance $(45,107)$.

If apoptotic cells fail to be cleared efficiently, they may become necrotic and expel self-antigens and TLR ligands that are opsonized by autoantibodies, forming immune complexes $(125,126)$. Like apoptotic cells, immune complexes (ICs) present self-antigens in a multimeric form and enhance phagocytosis by DCs and MФs (127, 128). While apoptotic cells stimulate anti-inflammatory responses, ICs bind to Fc receptors (FcRs) and elicit inflammatory responses from MФs and DCs (128). Individual FcRs have distinct activating and inhibitory functions to ensure balance in a normal immune system. Activating FcRs include Fc $\gamma$ RI and Fc $\gamma$ RIII, which phagocytose ICs and provoke inflammatory responses from DCs and MФs (129-131). These receptors are necessary and sufficient for glomerulonephritis in (NZB/NZW) F1 mice (132-134). Co- 
ligation of TLR9 and Fc $\gamma$ RIII by chromatin:IC induces more DC activation than ligation of FcyRIII alone, indicating that TLRs synergize with FcR signaling (135). In contrast to the activating FcRs, FcrRIIB is an inhibitory FcR with various functions depending on cell type. It modulates $\mathrm{M} \Phi$ phagocytosis, DC maturation, BCR signaling, IgG secretion, and the expansion of autoreactive IgG-producing B cells (134, 136-145). Autoantibodies and glomerulonephritis develop in certain strains of mice deficient in Fc $\gamma$ RIIB, affirming its role in preventing autoreactive B cell activation (146, 147). Additionally, antigen internalized by DCs through Fc $\gamma$ RIIB, but not Fc $\gamma$ RI or Fc $\gamma$ RIII, is presented in its native form and activates antigen-specific B cells (148). Immune complexes and FcRs have important roles in the immune system, but their dysregulation can result in autoantibody secretion and nephritis.

Clearance of apoptotic cells and their associated autoantigens is crucial in preventing activation of B cells, DCs, MФs, and T cells. When mice are immunized with apoptotic cells or exhibit a defect in apoptotic cell clearance, Sm-specific antibodies are detectable in the serum and MZ and B-1 B cells are inappropriately activated $(66,68,69)$. This suggests that recognition of autoantigens on apoptotic cells can drive B cell terminal differentiation $(66,68)$. Impaired clearance of apoptotic cells in $\mathrm{Fas}^{l p r}(69)$ and $\mathrm{mer}^{\mathrm{kd}}$ $(149,150)$ mice prevents BCR-mediated reprogramming of IL-6R and CD40 (unpublished data). These data suggest that exposure of autoreactive B cells to apoptotic cells or immune complexes can impact DC/M $\Phi$-mediated tolerance. In summary, apoptotic cells and the self-antigens they display can play both autoimmune and antiinflammatory roles. Imbalances in apoptotic cell clearance or cellular responses result in inflammatory responses and autoimmune disease. 


\subsection{Selective repression: new treatments for SLE?}

Systemic lupus erythematosus (SLE) is primarily a B cell-mediated autoimmune disease, with symptoms arising from autoantibody deposition and inflammation in target organs, such as the kidneys, skin, and brain. Until recently, treatments for SLE were dependent on immunosuppression, which depresses immune function and causes dangerous side effects such as opportunistic infections (151). Therapies that target specific cell types or biological processes are now being developed, with the hopes that they will be more powerful and have less harmful side effects. For instance, chimeric anti-CD20 (rituximab), depletes peripheral B cells and reduces the severity of SLE symptoms in many patients (152). However, a subset of patients is resistant to rituximab treatment (151). Additionally, rituximab recently failed a late-stage study when its efficacy in achieving a clinical response was no greater than a placebo (153). In murine studies of human CD20, B cells in autoimmune-prone strains were refractory to depletion by rituximab (154), compared to non-autoimmune-prone strains. Other biological agents being studied or developed target complement activation, B cell-T cell interactions, cytokines, TLRs, interferon, or direct removal of antibodies from circulation. However, developing therapies to target each lupus-related autoantigen would be cumbersome and slow. A more efficient approach would be a therapy that selectively targeted autoreactive B cells through a common trait to restore tolerance. In previous studies, we determined that DC- and MФ-mediated repression via IL-6 and sCD40L is effective on B cells of multiple specificities. These data suggest that any B cell chronically exposed to antigen would be susceptible to DC/MФ-mediated tolerance. We are currently determining whether the lack of these soluble factors promotes autoimmunity in normal mice during 
innate immune responses. Preliminary data indicate that $\mathrm{Sm}$-specific B cells adoptively transferred into chimeric mice lacking IL-6 and SCD40L become activated and secrete autoantibodies (unpublished data). This is consistent with our model indicating that DCs/MФs and their secreted products regulate autoreactive B cells during innate immune responses. Future experiments will examine if tolerance can be restored in lupus-prone mice reconstituted with a mix of autoimmune and non-autoimmune hematopoietic stem cells. If DC/M $\Phi$-mediated tolerance is found to be defective in SLE patients, future therapies could target their in vivo activation or introduce normal DCs/MФs to reinstate B cell tolerance of newly emerging B cells following B cell depletion therapy. One approach would be nonmyeloablative bone marrow transplant (BMT) or nonmyeloablative hematopoietic stem cell transplant (HSCT) to promote mixed chimerism. This may reinstate tolerance by providing a pool of DCs/MФs that repress autoreactive B cells. Such an approach has shown promise in controlling B cell mediated autoimmune disease in humans and mouse models (155-160), resulting in remission of rheumatoid arthritis in a human patient (158) and reduction in lupus-like disease in mice $(155,157)$.

\section{$\underline{1.7 \text { Summary }}$}

The autoreactive B cells that incite multi-organ damage in SLE patients become dysregulated long before clinical symptoms appear. Autoantigens and TLR ligands released from apoptotic cells can overcome the tolerance of autoreactive B cells. Autoreactive $\mathrm{T}$ cells provide costimulation and promote the secretion of high-affinity, class-switched autoantibodies. These autoantibodies can bind nuclear self-antigens, form 
immune complexes, and provoke inflammatory responses from DCs and MФs.

Fortunately, DCs and MФs specifically repress autoreactive B cells during TLR stimulation by secreting IL-6 and sCD40L. Restoring normal DC and M $\Phi$ function in SLE patients might repress autoreactive B cells and re-establish balance among the complex components of the immune system. 


\section{$\underline{1.8 \text { References }}$}

1. Nemazee, D. A., and K. Burki. 1989. Clonal deletion of B lymphocytes in a transgenic mouse bearing anti-MHC class I antibody genes. Nature 337:562.

2. Lang, J., M. Jackson, L. Teyton, A. Brunmark, K. Kane, and D. Nemazee. 1996. B cells are exquisitely sensitive to central tolerance and receptor editing induced by ultralow affinity, membrane-bound antigen. J Exp Med 184:1685.

3. Halverson, R., R. M. Torres, and R. Pelanda. 2004. Receptor editing is the main mechanism of B cell tolerance toward membrane antigens. Nat Immunol 5:645.

4. Hippen, K. L., B. R. Schram, L. E. Tze, K. A. Pape, M. K. Jenkins, and T. W. Behrens. 2005. In vivo assessment of the relative contributions of deletion, anergy, and editing to B cell self-tolerance. J Immunol 175:909.

5. Retter, M. W., and D. Nemazee. 1998. Receptor editing occurs frequently during normal B cell development. J Exp Med 188:1231.

6. Casellas, R., T. A. Shih, M. Kleinewietfeld, J. Rakonjac, D. Nemazee, K. Rajewsky, and M. C. Nussenzweig. 2001. Contribution of receptor editing to the antibody repertoire. Science 291:1541.

7. Ait-Azzouzene, D., L. Verkoczy, J. Peters, A. Gavin, P. Skog, J. L. Vela, and D. Nemazee. 2005. An immunoglobulin C kappa-reactive single chain antibody fusion protein induces tolerance through receptor editing in a normal polyclonal immune system. J Exp Med 201:817.

8. Nemazee, D., and M. Weigert. 2000. Revising B Cell Receptors. J. Exp. Med. 191:1813.

9. Gay, D., T. Saunders, S. Camper, and M. Weigert. 1993. Receptor editing: an approach by autoreactive B cells to escape tolerance. J Exp Med 177:999.

10. Tiegs, S. L., D. M. Russell, and D. Nemazee. 1993. Receptor editing in selfreactive bone marrow B cells. J Exp Med 177:1009.

11. Han, S., S. R. Dillon, B. Zheng, M. Shimoda, M. S. Schlissel, and G. Kelsoe. 1997. V(D)J recombinase activity in a subset of germinal center B lymphocytes. Science 278:301.

12. Papavasiliou, F., R. Casellas, H. Suh, X. F. Qin, E. Besmer, R. Pelanda, D. Nemazee, K. Rajewsky, and M. C. Nussenzweig. 1997. V(D)J recombination in mature B cells: a mechanism for altering antibody responses. Science 278:298. 
13. Han, S., B. Zheng, D. G. Schatz, E. Spanopoulou, and G. Kelsoe. 1996. Neoteny in lymphocytes: Rag1 and Rag2 expression in germinal center B cells. Science 274:2094.

14. Hikida, M., M. Mori, T. Takai, K. Tomochika, K. Hamatani, and H. Ohmori. 1996. Reexpression of RAG-1 and RAG-2 genes in activated mature mouse B cells. Science 274:2092.

15. Russell, D. M., Z. Dembic, G. Morahan, J. F. A. P. Miller, K. BUrki, and D. Nemazee. 1991. Peripheral deletion of self-reactive B cells. 354:308.

16. Kench, J. A., D. M. Russell, and D. Nemazee. 1998. Efficient Peripheral Clonal Elimination of B Lymphocytes in MRL/lpr Mice Bearing Autoantibody Transgenes. J. Exp. Med. 188:909.

17. Cyster, J. G., S. B. Hartley, and C. C. Goodnow. 1994. Competition for follicular niches excludes self-reactive cells from the recirculating B-cell repertoire. Nature 371:389.

18. Cyster, J. G., and C. C. Goodnow. 1995. Antigen-induced exclusion from follicles and anergy are separate and complementary processes that influence peripheral B cell fate. Immunity 3:691.

19. Schmidt, K. N., and J. G. Cyster. 1999. Follicular exclusion and rapid elimination of hen egg lysozyme autoantigen-binding B cells are dependent on competitor B cells, but not on T cells. J Immunol 162:284.

20. Ekland, E. H., R. Forster, M. Lipp, and J. G. Cyster. 2004. Requirements for follicular exclusion and competitive elimination of autoantigen-binding B cells. $J$ Immunol 172:4700.

21. Paul, E., A. Nelde, A. Verschoor, and M. C. Carroll. 2007. Follicular exclusion of autoreactive B cells requires Fc \{gamma\}RIIb. Int. Immunol. 19:365.

22. Mandik-Nayak, L., S. Seo, A. Eaton-Bassiri, D. Allman, R. R. Hardy, and J. Erikson. 2000. Functional consequences of the developmental arrest and follicular exclusion of anti-double-stranded DNA B cells. J Immunol 164:1161.

23. Aplin, B. D., C. L. Keech, A. L. de Kauwe, T. P. Gordon, D. Cavill, and J. McCluskey. 2003. Tolerance through Indifference: Autoreactive B Cells to the Nuclear Antigen La Show No Evidence of Tolerance in a Transgenic Model $J$ Immunol 171:5890.

24. Koenig-Marrony, S., P. Soulas, S. Julien, A.-M. Knapp, J.-C. Garaud, T. Martin, and J.-L. Pasquali. 2001. Natural Autoreactive B Cells in Transgenic Mice 
Reproduce an Apparent Paradox to the Clonal Tolerance Theory. J Immunol 166:1463.

25. Liu, X., and T. Manser. 2005. Antinuclear Antigen B Cells That Down-Regulate Surface B Cell Receptor during Development to Mature, Follicular Phenotype Do Not Display Features of Anergy In Vitro. J Immunol 174:4505.

26. Goodnow, C. C., J. Crosbie, S. Adelstein, T. B. Lavoie, S. J. Smith-Gill, R. A. Brink, H. Pritchard-Briscoe, J. S. Wotherspoon, R. H. Loblay, K. Raphael, and et al. 1988. Altered immunoglobulin expression and functional silencing of selfreactive B lymphocytes in transgenic mice. Nature 334:676.

27. Rui, L., C. G. Vinuesa, J. Blasioli, and C. C. Goodnow. 2003. Resistance to CpG DNA-induced autoimmunity through tolerogenic B cell antigen receptor ERK signaling. Nat Immunol 4:594.

28. Rui, L., J. I. Healy, J. Blasioli, and C. C. Goodnow. 2006. ERK signaling is a molecular switch integrating opposing inputs from $\mathrm{B}$ cell receptor and $\mathrm{T}$ cell cytokines to control TLR4-driven plasma cell differentiation. J Immunol 177:5337.

29. Nossal, G. J., and B. L. Pike. 1980. Clonal anergy: persistence in tolerant mice of antigen-binding B lymphocytes incapable of responding to antigen or mitogen. Proc Natl Acad Sci U S A 77:1602.

30. Noorchashm, H., A. Bui, H.-L. Li, A. Eaton, L. Mandik-Nayak, C. Sokol, K. M. Potts, E. Pure, and J. Erikson. 1999. Characterization of anergic anti-DNA B cells: B cell anergy is a T cell-independent and potentially reversible process. Int. Immunol. 11:765.

31. Acevedo-Suarez, C. A., C. Hulbert, E. J. Woodward, and J. W. Thomas. 2005. Uncoupling of anergy from developmental arrest in anti-insulin B cells supports the development of autoimmune diabetes. J Immunol 174:827.

32. Borrero, M., and S. H. Clarke. 2002. Low-affinity anti-Smith antigen B cells are regulated by anergy as opposed to developmental arrest or differentiation to B-1. J Immunol 168:13.

33. Benschop, R. J., K. Aviszus, X. Zhang, T. Manser, J. C. Cambier, and L. J. Wysocki. 2001. Activation and anergy in bone marrow B cells of a novel immunoglobulin transgenic mouse that is both hapten specific and autoreactive. Immunity 14:33.

34. Merrell, K. T., R. J. Benschop, S. B. Gauld, K. Aviszus, D. Decote-Ricardo, L. J. Wysocki, and J. C. Cambier. 2006. Identification of anergic B cells within a wildtype repertoire. Immunity 25:953. 
35. Santulli-Marotto, S., M. W. Retter, R. Gee, M. J. Mamula, and S. H. Clarke. 1998. Autoreactive B Cell Regulation: Peripheral Induction of Developmental Arrest by Lupus-Associated Autoantigens. Immunity 8:209.

36. Nguyen, K. A., L. Mandik, A. Bui, J. Kavaler, A. Norvell, J. G. Monroe, J. H. Roark, and J. Erikson. 1997. Characterization of anti-single-stranded DNA B cells in a non-autoimmune background. J Immunol 159:2633.

37. Busconi, L., J. W. Bauer, J. R. Tumang, A. Laws, K. Perkins-Mesires, A. S. Tabor, C. Lau, R. B. Corley, T. L. Rothstein, F. E. Lund, T. W. Behrens, and A. Marshak-Rothstein. 2007. Functional Outcome of B Cell Activation by Chromatin Immune Complex Engagement of the B Cell Receptor and TLR9. $J$ Immunol 179:7397.

38. Leadbetter, E. A., I. R. Rifkin, A. M. Hohlbaum, B. C. Beaudette, M. J. Shlomchik, and A. Marshak-Rothstein. 2002. Chromatin-IgG complexes activate B cells by dual engagement of IgM and Toll-like receptors. Nature 416:603.

39. Lau, C. M., C. Broughton, A. S. Tabor, S. Akira, R. A. Flavell, M. J. Mamula, S. R. Christensen, M. J. Shlomchik, G. A. Viglianti, I. R. Rifkin, and A. MarshakRothstein. 2005. RNA-associated autoantigens activate B cells by combined B cell antigen receptor/Toll-like receptor 7 engagement. J. Exp. Med. 202:1171.

40. Acevedo-Suarez, C. A., D. M. Kilkenny, M. B. Reich, and J. W. Thomas. 2006. Impaired Intracellular Calcium Mobilization and NFATc1 Availability in Tolerant Anti-Insulin B Cells. J Immunol 177:2234.

41. Cooke, M. P., A. W. Heath, K. M. Shokat, Y. Zeng, F. D. Finkelman, P. S. Linsley, M. Howard, and C. C. Goodnow. 1994. Immunoglobulin signal transduction guides the specificity of B cell-T cell interactions and is blocked in tolerant self-reactive B cells. J Exp Med 179:425.

42. Gauld, S. B., R. J. Benschop, K. T. Merrell, and J. C. Cambier. 2005. Maintenance of B cell anergy requires constant antigen receptor occupancy and signaling. Nat Immunol 6:1160.

43. Goodnow, C. C., J. Crosbie, H. Jorgensen, R. A. Brink, and A. Basten. 1989. Induction of self-tolerance in mature peripheral B lymphocytes. Nature 342:385.

44. Kilmon, M. A., J. A. Rutan, S. H. Clarke, and B. J. Vilen. 2005. Low-affinity, Smith antigen-specific B cells are tolerized by dendritic cells and macrophages. $J$ Immunol 175:37. 
45. Kilmon, M. A., N. J. Wagner, A. L. Garland, L. Lin, K. Aviszus, L. J. Wysocki, and B. J. Vilen. 2007. Macrophages prevent the differentiation of autoreactive B cells by secreting CD40 ligand and interleukin-6. Blood 110:1595.

46. Kouskoff, V., S. Famiglietti, G. Lacaud, P. Lang, J. E. Rider, B. K. Kay, J. C. Cambier, and D. Nemazee. 1998. Antigens Varying in Affinity for the B Cell Receptor Induce Differential B Lymphocyte Responses. J. Exp. Med. 188:1453.

47. Tan, E. M., and H. G. Kunkel. 2006. Pillars Article: Characteristics of a Soluble Nuclear Antigen Precipitating with Sera of Patients with Systemic Lupus Erythematosus. J. Immunol. 1966. 96: 464-471. J Immunol 176:1297.

48. Tan, E. M., A. S. Cohen, J. F. Fries, A. T. Masi, D. J. McShane, N. F. Rothfield, J. G. Schaller, N. Talal, and R. J. Winchester. 1982. The 1982 revised criteria for the classification of systemic lupus erythematosus. Arthritis Rheum 25:1271.

49. Clotet, B., J. Guardia, C. Pigrau, E. Lience, C. Murcia, R. Pujol, and R. Bacardi. 1984. Incidence and clinical significance of anti-ENA antibodies in systemic lupus erythematosus. Estimation by counterimmunoelectrophoresis. Scand $J$ Rheumatol 13:15.

50. Martinez-Cordero, E., E. Martinez-Miranda, M. C. Negrete-Garcia, A. Padilla, and D. E. Aguilar Leon. 1992. Anti-dsDNA and Sm autoantibodies in systemic lupus erythematosus. Clin Rheumatol 11:341.

51. Gripenberg, M., A. M. Teppo, and C. Friman. 1991. Antibodies to Sm and SS-A demonstrated by enzyme immunoassay. Correlation to clinical manifestations and disease activity in patients with systemic lupus erythematosus. Rheumatol Int 11:209.

52. Barada, F. A., Jr., B. S. Andrews, J. S. t. Davis, and R. P. Taylor. 1981. Antibodies to Sm in patients with systemic lupus erythematosus. Correlation of Sm antibody titers with disease activity and other laboratory parameters. Arthritis Rheum 24:1236.

53. Lopez-Longo, F. J., C. M. Gonzalez Fernandez, M. Rodriguez Mahou, R. Grau Simo, I. Monteagudo Saez, A. C. Meno Garcia, and L. Carreno Perez. 1997. [Clinical expression of systemic lupus erythematosus with anti-U1-RNP and antiSm antibodies]. Rev Clin Esp 197:329.

54. Lerner, M. R., and J. A. Steitz. 1979. Antibodies to Small Nuclear RNAs Complexed with Proteins are Produced by Patients with Systemic Lupus Erythematosus. Proceedings of the National Academy of Sciences 76:5495. 
55. Stark, H., P. Dube, R. Luhrmann, and B. Kastner. 2001. Arrangement of RNA and proteins in the spliceosomal U1 small nuclear ribonucleoprotein particle. 409:539.

56. Zhang, D., N. Abovich, and M. Rosbash. 2001. A Biochemical Function for the Sm Complex. Molecular Cell 7:319.

57. Seraphin, B., and M. Rosbash. 1989. Identification of functional U1 snRNA-premRNA complexes committed to spliceosome assembly and splicing. Cell 59:349.

58. Staley, J. P., and C. Guthrie. 1998. Mechanical devices of the spliceosome: motors, clocks, springs, and things. Cell 92:315.

59. Marshak-Rothstein, A., L. Busconi, C. M. Lau, A. S. Tabor, E. A. Leadbetter, S. Akira, A. M. Krieg, G. B. Lipford, G. A. Viglianti, and I. R. Rifkin. 2004. Comparison of $\mathrm{CpG}$ s-ODNs, chromatin immune complexes, and dsDNA fragment immune complexes in the TLR9-dependent activation of rheumatoid factor B cells. J Endotoxin Res 10:247.

60. Rifkin, I. R., E. A. Leadbetter, B. C. Beaudette, C. Kiani, M. Monestier, M. J. Shlomchik, and A. Marshak-Rothstein. 2000. Immune complexes present in the sera of autoimmune mice activate rheumatoid factor B cells. J Immunol 165:1626.

61. Eric L. Greidinger, R. W. H. 2001. The appearance of U1 RNP antibody specificities in sequential autoimmune human antisera follows a characteristic order that implicates the U1-70 $\mathrm{kd}$ and Bprime/B proteins as predominant U1 RNP immunogens. Arthritis \& Rheumatism 44:368.

62. Crozat, K., and B. Beutler. 2004. TLR7: A new sensor of viral infection. Proceedings of the National Academy of Sciences 101:6835.

63. Deane, J. A., P. Pisitkun, R. S. Barrett, L. Feigenbaum, T. Town, J. M. Ward, R. A. Flavell, and S. Bolland. 2007. Control of toll-like receptor 7 expression is essential to restrict autoimmunity and dendritic cell proliferation. Immunity 27:801.

64. Pisitkun, P., J. A. Deane, M. J. Difilippantonio, T. Tarasenko, A. B. Satterthwaite, and S. Bolland. 2006. Autoreactive B cell responses to RNA-related antigens due to TLR7 gene duplication. Science 312:1669.

65. Santulli-Marotto, S., Y. Qian, S. Ferguson, and S. H. Clarke. 2001. Anti-Sm B Cell Differentiation in Ig Transgenic MRL/Mp-lpr/lpr Mice: Altered Differentiation and an Accelerated Response. J Immunol 166:5292.

66. Qian, Y., C. Santiago, M. Borrero, T. F. Tedder, and S. H. Clarke. 2001. LupusSpecific Antiribonucleoprotein B Cell Tolerance in Nonautoimmune Mice Is 
Maintained by Differentiation to B-1 and Governed by B Cell Receptor Signaling Thresholds. J Immunol 166:2412.

67. Chuanlin Ding, L. W., Hayma AL-Ghawi, Jose Marroquin, Mark Mamula, Jun Yan,. 2006. Toll-like receptor engagement stimulates anti-snRNP autoreactive B cells for activation. European Journal of Immunology 36:2013.

68. Qian, Y., H. Wang, and S. H. Clarke. 2004. Impaired clearance of apoptotic cells induces the activation of autoreactive anti-Sm marginal zone and B-1 B cells. $J$ Immunol 172:625.

69. Qian, Y., K. L. Conway, X. Lu, H. M. Seitz, G. K. Matsushima, and S. H. Clarke. 2006. Autoreactive MZ and B-1 B-cell activation by Faslpr is coincident with an increased frequency of apoptotic lymphocytes and a defect in macrophage clearance. Blood 108:974.

70. Diz, R., S. K. McCray, and S. H. Clarke. 2008. BCR affinity and B cell subset identity integrate to define the effectiveness, affinity threshold, and mechanism of anergy. J Immunol In press.

71. Yan, J., and M. J. Mamula. 2002. B and T cell tolerance and autoimmunity in autoantibody transgenic mice. Int Immunol 14:963.

72. Bowen, F., J. Haluskey, and H. Quill. 1995. Altered CD40 ligand induction in tolerant T lymphocytes. Eur J Immunol 25:2830.

73. Craft, J., S. Peng, T. Fujii, M. Okada, and S. Fatenejad. 1999. Autoreactive T cells in murine lupus: origins and roles in autoantibody production. Immunol Res 19:245.

74. Peng, S. L., S. Fatenejad, and J. Craft. 1996. Induction of nonpathologic, humoral autoimmunity in lupus-prone mice by a class II-restricted, transgenic alpha beta T cell. Separation of autoantigen-specific and -nonspecific help. J Immunol 157:5225.

75. Chan, O., and M. J. Shlomchik. 1998. A new role for B cells in systemic autoimmunity: B cells promote spontaneous T cell activation in MRL-lpr/lpr mice. J Immunol 160:51.

76. Yan, J., B. P. Harvey, R. J. Gee, M. J. Shlomchik, and M. J. Mamula. 2006. B cells drive early $\mathrm{T}$ cell autoimmunity in vivo prior to dendritic cell-mediated autoantigen presentation. J Immunol 177:4481.

77. Pasare, C., and R. Medzhitov. 2003. Toll Pathway-Dependent Blockade of CD4+CD25+ T Cell-Mediated Suppression by Dendritic Cells. Science 299:1033. 
78. Jego, G., A. K. Palucka, J. P. Blanck, C. Chalouni, V. Pascual, and J. Banchereau. 2003. Plasmacytoid dendritic cells induce plasma cell differentiation through type I interferon and interleukin 6. Immunity 19:225.

79. Balazs, M., F. Martin, T. Zhou, and J. Kearney. 2002. Blood dendritic cells interact with splenic marginal zone B cells to initiate T-independent immune responses. Immunity 17:341.

80. Craxton, A., D. Magaletti, E. J. Ryan, and E. A. Clark. 2003. Macrophage- and dendritic cell--dependent regulation of human $\mathrm{B}$-cell proliferation requires the TNF family ligand BAFF. Blood 101:4464.

81. Mitani, Y., A. Takaoka, S. Kim, Y. Kato, T. Yokochi, N. Tanaka, and T. Taniguchi. 2001. Cross talk of the interferon-alpha/beta signalling complex with gp130 for effective interleukin-6 signalling. Genes to Cells 6:631.

82. Dye, J. R., A. Palvanov, B. Guo, and T. L. Rothstein. 2007. B Cell Receptor Cross-Talk: Exposure to Lipopolysaccharide Induces an Alternate Pathway for B Cell Receptor-Induced ERK Phosphorylation and NF-\{kappa\}B Activation. $J$ Immunol 179:229.

83. Guo, B., and T. L. Rothstein. 2005. B Cell Receptor (BCR) Cross-Talk: IL-4 Creates an Alternate Pathway for BCR-Induced ERK Activation That Is Phosphatidylinositol 3-Kinase Independent. J Immunol 174:5375.

84. Guo, B., D. Blair, T. C. Chiles, C. A. Lowell, and T. L. Rothstein. 2007. Cutting Edge: B cell receptor (BCR) cross-talk: the IL-4-induced alternate pathway for $\mathrm{BCR}$ signaling operates in parallel with the classical pathway, is sensitive to Rottlerin, and depends on Lyn. J Immunol 178:4726.

85. Mizuno, T., and T. L. Rothstein. 2005. B cell receptor (BCR) cross-talk: CD40 engagement creates an alternate pathway for BCR signaling that activates I kappa B kinase/I kappa B alpha/NF-kappa B without the need for PI3K and phospholipase C gamma. J Immunol 174:6062.

86. Mizuno, T., and T. L. Rothstein. 2005. B cell receptor (BCR) cross-talk: CD40 engagement enhances BCR-induced ERK activation. J Immunol 174:3369.

87. Healy, J. I., R. E. Dolmetsch, L. A. Timmerman, J. G. Cyster, M. L. Thomas, G. R. Crabtree, R. S. Lewis, and C. C. Goodnow. 1997. Different Nuclear Signals Are Activated by the B Cell Receptor during Positive Versus Negative Signaling. Immunity 6:419.

88. Karlsson, M. C., R. Guinamard, S. Bolland, M. Sankala, R. M. Steinman, and J. V. Ravetch. 2003. Macrophages control the retention and trafficking of B lymphocytes in the splenic marginal zone. J Exp Med 198:333. 
89. Andrews, B., R. Eisenberg, A. Theofilopoulos, S. Izui, C. Wilson, P. McConahey, E. Murphy, J. Roths, and F. Dixon. 1978. Spontaneous murine lupus-like syndromes. Clinical and immunopathological manifestations in several strains. $J$. Exp. Med. 148:1198.

90. Tan, E. M. 1989. Antinuclear antibodies: diagnostic markers for autoimmune diseases and probes for cell biology. Adv Immunol 44:93.

91. Lamoureux, J. L., L. C. Watson, M. Cherrier, P. Skog, D. Nemazee, and A. J. Feeney. 2007. Reduced receptor editing in lupus-prone MRL/lpr mice. J. Exp. Med. 204:2853.

92. Mandik-Nayak, L., S.-j. Seo, C. Sokol, K. M. Potts, A. Bui, and J. Erikson. 1999. MRL-lpr/lpr Mice Exhibit a Defect in Maintaining Developmental Arrest and Follicular Exclusion of Anti-double-stranded DNA B Cells. J. Exp. Med. 189:1799.

93. Culton, D. A., B. P. O'Conner, K. L. Conway, R. Diz, J. Rutan, B. J. Vilen, and S. H. Clarke. 2006. Early preplasma cells define a tolerance checkpoint for autoreactive B cells. J Immunol 176:790.

94. Jiang, C., J. Foley, N. Clayton, G. Kissling, M. Jokinen, R. Herbert, and M. Diaz. 2007. Abrogation of Lupus Nephritis in Activation-Induced Deaminase-Deficient MRL/lpr Mice. J Immunol 178:7422.

95. Hang, L., A. N. Theofilopoulos, R. S. Balderas, S. J. Francis, and F. J. Dixon. 1984. The effect of thymectomy on lupus-prone mice. J Immunol 132:1809.

96. Peng, S. L., M. P. Madaio, D. P. Hughes, I. N. Crispe, M. J. Owen, L. Wen, A. C. Hayday, and J. Craft. 1996. Murine lupus in the absence of alpha beta T cells. $J$ Immunol 156:4041.

97. Jevnikar, A. M., M. J. Grusby, and L. H. Glimcher. 1994. Prevention of nephritis in major histocompatibility complex class II-deficient MRL-lpr mice. J Exp Med 179:1137.

98. Koh, D. R., A. Ho, A. Rahemtulla, W. P. Fung-Leung, H. Griesser, and T. W. Mak. 1995. Murine lupus in MRL/lpr mice lacking CD4 or CD8 T cells. Eur J Immunol 25:2558.

99. Mudd, P. A., B. N. Teague, and A. D. Farris. 2006. Regulatory T cells and systemic lupus erythematosus. Scand J Immunol 64:211. 
100. Valencia, X., C. Yarboro, G. Illei, and P. E. Lipsky. 2007. Deficient CD4+CD25high T Regulatory Cell Function in Patients with Active Systemic Lupus Erythematosus. J Immunol 178:2579.

101. Philpott, K. L., J. L. Viney, G. Kay, S. Rastan, E. M. Gardiner, S. Chae, A. C. Hayday, and M. J. Owen. 1992. Lymphoid development in mice congenitally lacking T cell receptor alpha beta-expressing cells. Science 256:1448.

102. Sadanaga, A., H. Nakashima, M. Akahoshi, K. Masutani, K. Miyake, T. Igawa, N. Sugiyama, H. Niiro, and M. Harada. 2007. Protection against autoimmune nephritis in MyD88-deficient MRL/lpr mice. Arthritis Rheum 56:1618.

103. Christensen, S. R., J. Shupe, K. Nickerson, M. Kashgarian, R. A. Flavell, and M. J. Shlomchik. 2006. Toll-like receptor 7 and TLR9 dictate autoantibody specificity and have opposing inflammatory and regulatory roles in a murine model of lupus. Immunity 25:417.

104. Moseman, E. A., X. Liang, A. J. Dawson, A. Panoskaltsis-Mortari, A. M. Krieg, Y. J. Liu, B. R. Blazar, and W. Chen. 2004. Human plasmacytoid dendritic cells activated by $\mathrm{CpG}$ oligodeoxynucleotides induce the generation of CD4+CD25+ regulatory T cells. J Immunol 173:4433.

105. Obermeier, F., U. G. Strauch, N. Dunger, N. Grunwald, H. C. Rath, H. Herfarth, J. Scholmerich, and W. Falk. 2005. In vivo CpG DNA/toll-like receptor 9 interaction induces regulatory properties in $\mathrm{CD} 4+\mathrm{CD} 62 \mathrm{~L}+\mathrm{T}$ cells which prevent intestinal inflammation in the SCID transfer model of colitis. Gut 54:1428.

106. Wu, X., and S. L. Peng. 2006. Toll-like receptor 9 signaling protects against murine lupus. Arthritis Rheum 54:336.

107. Gilbert, M. R., D. G. Carnathan, P. C. Cogswell, L. Lin, A. S. Baldwin, Jr., and B. J. Vilen. 2007. Dendritic cells from lupus-prone mice are defective in repressing immunoglobulin secretion. J Immunol 178:4803.

108. Munoz, L. E., U. S. Gaipl, S. Franz, A. Sheriff, R. E. Voll, J. R. Kalden, and M. Herrmann. 2005. SLE--a disease of clearance deficiency? Rheumatology 44:1101.

109. Casiano, C. A., S. J. Martin, D. R. Green, and E. M. Tan. 1996. Selective cleavage of nuclear autoantigens during CD95 (Fas/APO-1)-mediated T cell apoptosis. J Exp Med 184:765.

110. Utz, P. J., M. Hottelet, T. M. Le, S. J. Kim, M. E. Geiger, W. J. van Venrooij, and P. Anderson. 1998. The 72-kDa component of signal recognition particle is cleaved during apoptosis. J Biol Chem 273:35362. 
111. Utz, P. J., M. Hottelet, P. H. Schur, and P. Anderson. 1997. Proteins phosphorylated during stress-induced apoptosis are common targets for autoantibody production in patients with systemic lupus erythematosus. $J$ Exp Med 185:843.

112. Cocca, B. A., A. M. Cline, and M. Z. Radic. 2002. Blebs and Apoptotic Bodies Are B Cell Autoantigens. J Immunol 169:159.

113. Casciola-Rosen, L., G. Anhalt, and A. Rosen. 1994. Autoantigens targeted in systemic lupus erythematosus are clustered in two populations of surface structures on apoptotic keratinocytes. J. Exp. Med. 179:1317.

114. Radic, M., T. Marion, and M. Monestier. 2004. Nucleosomes Are Exposed at the Cell Surface in Apoptosis. J Immunol 172:6692.

115. Frisoni, L., L. McPhie, S.-A. Kang, M. Monestier, M. Madaio, M. Satoh, and R. Caricchio. 2007. Lack of Chromatin and Nuclear Fragmentation In Vivo Impairs the Production of Lupus Anti-Nuclear Antibodies. J Immunol 179:7959.

116. Fadok, V. A., D. L. Bratton, A. Konowal, P. W. Freed, J. Y. Westcott, and P. M. Henson. 1998. Macrophages that have ingested apoptotic cells in vitro inhibit proinflammatory cytokine production through autocrine/paracrine mechanisms involving TGF-beta, PGE2, and PAF. J Clin Invest 101:890.

117. Huynh, M. L., V. A. Fadok, and P. M. Henson. 2002. Phosphatidylserinedependent ingestion of apoptotic cells promotes TGF-betal secretion and the resolution of inflammation. J Clin Invest 109:41.

118. Voll, R. E., M. Herrmann, E. A. Roth, C. Stach, J. R. Kalden, and I. Girkontaite. 1997. Immunosuppressive effects of apoptotic cells. Nature 390:350.

119. Stuart, L. M., M. Lucas, C. Simpson, J. Lamb, J. Savill, and A. Lacy-Hulbert. 2002. Inhibitory Effects of Apoptotic Cell Ingestion upon Endotoxin-Driven Myeloid Dendritic Cell Maturation. J Immunol 168:1627.

120. Sen, P., M. A. Wallet, Z. Yi, Y. Huang, M. Henderson, C. E. Mathews, H. S. Earp, G. Matsushima, A. S. Baldwin, Jr., and R. M. Tisch. 2007. Apoptotic cells induce Mer tyrosine kinase-dependent blockade of NF-kappaB activation in dendritic cells. Blood 109:653.

121. Wallet, M. A., P. Sen, R. R. Flores, Y. Wang, Z. Yi, Y. Huang, C. E. Mathews, H. S. Earp, G. Matsushima, B. Wang, and R. Tisch. 2008. MerTK is required for apoptotic cell-induced T cell tolerance. J Exp Med 205:219. 
122. Licht, R., J. W. C. Dieker, C. W. M. Jacobs, W. J. M. Tax, and J. H. M. Berden. 2004. Decreased phagocytosis of apoptotic cells in diseased SLE mice. Journal of Autoimmunity 22:139.

123. Baumann, I., W. Kolowos, R. E. Voll, B. Manger, U. Gaipl, W. L. Neuhuber, T. Kirchner, J. R. Kalden, and M. Herrmann. 2002. Impaired uptake of apoptotic cells into tingible body macrophages in germinal centers of patients with systemic lupus erythematosus. Arthritis Rheum 46:191.

124. Martin Herrmann, R. E. V., Otmar M. Zoller, Manuela Hagenhofer, Botond B. Ponner, Joachim R. Kalden,. 1998. Impaired phagocytosis of apoptotic cell material by monocyte-derived macrophages from patients with systemic lupus erythematosus. Arthritis \& Rheumatism 41:1241.

125. Ren, Y., and J. Savill. 1998. Apoptosis: the importance of being eaten. Cell Death Differ 5:563.

126. Májai, G., G. Petrovski, and L. Fésüs. 2006. Inflammation and the apoptophagocytic system. Immunology Letters: Signals and Signal Processing in the Immune System 104:94.

127. Frisoni, L., L. Mcphie, L. Colonna, U. Sriram, M. Monestier, S. Gallucci, and R. Caricchio. 2005. Nuclear Autoantigen Translocation and Autoantibody Opsonization Lead to Increased Dendritic Cell Phagocytosis and Presentation of Nuclear Antigens: A Novel Pathogenic Pathway for Autoimmunity? . J Immunol 175:2692.

128. Angelo A. Manfredi, P. R., Giacomo Galati, Silvia Heltai, Enrica Bozzolo, Laura Soldini, Jean Davoust, Genesio Balestrieri, Angela Tincani, Maria Grazia Sabbadini,. 1998. Apoptotic cell clearance in systemic lupus erythematosus: I. Opsonization by antiphospholipid antibodies. Arthritis \& Rheumatism 41:205.

129. Gerber, J. S., and D. M. Mosser. 2001. Stimulatory and inhibitory signals originatingfrom the macrophage $\mathrm{Fc}$ [gamma] receptors. Microbes and Infection $3: 131$.

130. Barnes, N., A. L. Gavin, P. S. Tan, P. Mottram, F. Koentgen, and P. M. Hogarth. 2002. Fc[gamma]RI-Deficient Mice Show Multiple Alterations to Inflammatory and Immune Responses. Immunity 16:379.

131. Regnault, A., D. Lankar, V. Lacabanne, A. Rodriguez, C. Thery, M. Rescigno, T. Saito, S. Verbeek, C. Bonnerot, P. Ricciardi-Castagnoli, and S. Amigorena. 1999. Fcgamma Receptor-mediated Induction of Dendritic Cell Maturation and Major Histocompatibility Complex Class I-restricted Antigen Presentation after Immune Complex Internalization. J. Exp. Med. 189:371. 
132. Bergtold, A., A. Gavhane, V. D'Agati, M. Madaio, and R. Clynes. 2006. FcRBearing Myeloid Cells Are Responsible for Triggering Murine Lupus Nephritis. $J$ Immunol 177:7287.

133. Clynes, R., N. Calvani, B. P. Croker, and H. B. Richards. 2005. Modulation of the immune response in pristane-induced lupus by expression of activation and inhibitory Fc receptors. Clin Exp Immunol 141:230.

134. Clynes, R., C. Dumitru, and J. V. Ravetch. 1998. Uncoupling of Immune Complex Formation and Kidney Damage in Autoimmune Glomerulonephritis. Science 279:1052.

135. Boule, M. W., C. Broughton, F. Mackay, S. Akira, A. Marshak-Rothstein, and I. R. Rifkin. 2004. Toll-like Receptor 9-Dependent and -Independent Dendritic Cell Activation by Chromatin-Immunoglobulin G Complexes. J. Exp. Med. 199:1631.

136. Daeron, M., S. Latour, O. Malbec, E. Espinosa, P. Pina, S. Pasmans, and W. H. Fridman. 1995. The same tyrosine-based inhibition motif, in the intracytoplasmic domain of Fc gamma RIIB, regulates negatively BCR-, TCR-, and FcR-dependent cell activation. Immunity 3:635.

137. Takai, T., M. Ono, M. Hikida, H. Ohmori, and J. V. Ravetch. 1996. Augmented humoral and anaphylactic responses in Fc gamma RII-deficient mice. Nature 379:346.

138. Ono, M., S. Bolland, P. Tempst, and J. V. Ravetch. 1996. Role of the inositol phosphatase SHIP in negative regulation of the immune system by the receptor Fc(gamma)RIIB. Nature 383:263.

139. Coggeshall, K. M. 2000. Positive and negative signaling in B lymphocytes. Curr Top Microbiol Immunol 245:213.

140. Brauweiler, A., I. Tamir, S. Marschner, C. D. Helgason, and J. C. Cambier. 2001. Partially distinct molecular mechanisms mediate inhibitory FcgammaRIIB signaling in resting and activated B cells. J Immunol 167:204.

141. Bolland, S., and J. V. Ravetch. 1999. Inhibitory pathways triggered by ITIMcontaining receptors. Adv Immunol 72:149.

142. Clatworthy, M. R., and K. G. C. Smith. 2004. Fc\{gamma\}RIIb Balances Efficient Pathogen Clearance and the Cytokine-mediated Consequences of Sepsis. J. Exp. Med. 199:717.

143. Desai, D. D., S. O. Harbers, M. Flores, L. Colonna, M. P. Downie, A. Bergtold, S. Jung, and R. Clynes. 2007. Fc \{gamma $\}$ Receptor IIB on Dendritic Cells Enforces 
Peripheral Tolerance by Inhibiting Effector T Cell Responses. J Immunol 178:6217.

144. Fukuyama, H., F. Nimmerjahn, and J. V. Ravetch. 2005. The inhibitory Fcgamma receptor modulates autoimmunity by limiting the accumulation of immunoglobulin G+ anti-DNA plasma cells. Nat Immunol 6:99.

145. Brownlie, R. J., K. E. Lawlor, H. A. Niederer, A. J. Cutler, Z. Xiang, M. R. Clatworthy, R. A. Floto, D. R. Greaves, P. A. Lyons, and K. G. C. Smith. 2008. Distinct cell-specific control of autoimmunity and infection by Fc\{gamma\}RIIb. J. Exp. Med. 205:883.

146. Bolland, S., and J. V. Ravetch. 2000. Spontaneous autoimmune disease in $\mathrm{Fc}($ gamma)RIIB-deficient mice results from strain-specific epistasis. Immunity 13:277.

147. McGaha, T. L., M. C. I. Karlsson, and J. V. Ravetch. 2008. Fc\{gamma\}RIIB Deficiency Leads to Autoimmunity and a Defective Response to Apoptosis in Mrl-MpJ Mice. J Immunol 180:5670.

148. Bergtold, A., D. D. Desai, A. Gavhane, and R. Clynes. 2005. Cell surface recycling of internalized antigen permits dendritic cell priming of B cells. Immunity 23:503.

149. Camenisch, T. D., B. H. Koller, H. S. Earp2, and G. K. Matsushima. 1999. A Novel Receptor Tyrosine Kinase, Mer, Inhibits TNF-\{alpha\} Production and Lipopolysaccharide-Induced Endotoxic Shock. J Immunol 162:3498.

150. Cohen, P. L., R. Caricchio, V. Abraham, T. D. Camenisch, J. C. Jennette, R. A. Roubey, H. S. Earp, G. Matsushima, and E. A. Reap. 2002. Delayed apoptotic cell clearance and lupus-like autoimmunity in mice lacking the c-mer membrane tyrosine kinase. J Exp Med 196:135.

151. Sfikakis, P. P., J. N. Boletis, and G. C. Tsokos. 2005. Rituximab anti-B-cell therapy in systemic lupus erythematosus: pointing to the future. Curr Opin Rheumatol 17:550.

152. Maria J. Leandro, J. C. E., Geraldine Cambridge, Michael R. Ehrenstein, David A. Isenberg,. 2002. An open study of B lymphocyte depletion in systemic lupus erythematosus. Arthritis \& Rheumatism 46:2673.

153. Reuters. 2008. Biotech Drug Fails Critical Lupus Study. In The New York Times, New York. 
154. Ahuja, A., J. Shupe, R. Dunn, M. Kashgarian, M. R. Kehry, and M. J. Shlomchik. 2007. Depletion of B Cells in Murine Lupus: Efficacy and Resistance. J Immunol 179:3351.

155. Jones, O. Y., A. Steele, J. M. Jones, Y. Marikar, Y. Chang, A. Feliz, R. A. Cahill, and R. A. Good. 2004. Nonmyeloablative Bone Marrow Transplantation of BXSB Lupus Mice Using Fully Matched Allogeneic Donor Cells from Green Fluorescent Protein Transgenic Mice. J Immunol 172:5415.

156. Burt, R. K., S. Slavin, W. H. Burns, and A. M. Marmont. 2002. Induction of tolerance in autoimmune diseases by hematopoietic stem cell transplantation: getting closer to a cure? Blood 99:768.

157. Wang, B., Y. Yamamoto, N. S. El-Badri, and R. A. Good. 1999. Effective treatment of autoimmune disease and progressive renal disease by mixed bonemarrow transplantation that establishes a stable mixed chimerism in BXSB recipient mice. Proceedings of the National Academy of Sciences 96:3012.

158. Richard K. Burt, Y. O., Larissa Verda, Kathleen Quigley, Mary Brush, Kimberly Yaung, Laisvyde Statkute, Ann Traynor, Walter G. Barr,. 2004. Induction of remission of severe and refractory rheumatoid arthritis by allogeneic mixed chimerism. Arthritis \& Rheumatism 50:2466.

159. Flierman, R., H. J. Witteveen, E. I. H. van der Voort, T. W. J. Huizinga, R. R. P. de Vries, W. E. Fibbe, R. E. M. Toes, and J. M. van Laar. 2005. Control of systemic B cell-mediated autoimmune disease by nonmyeloablative conditioning and major histocompatibility complex-mismatched allogeneic bone marrow transplantation. Blood 105:2991.

160. Burt, R. K. 2005. From animals to clinic: nonmyeloablative conditioning and allogeneic bone marrow transplantation in autoimmune disease. Blood 105:2623. 


\subsection{Figures}

Figure 1.1. DCs and MФs repress antibody secretion from autoreactive $B$ cells via IL-6 and SCD40L. (A) In non-autoimmune mice, B cell tolerance is maintained during innate immune responses by DCs and MФs. Although TLR stimulation promotes Ig secretion by B cells, it simultaneously induces DCs and MФs to secrete IL-6 and sCD40L. These soluble factors repress Ig secretion from autoreactive B cells while allowing innate stimuli to produce a polyclonal response by naïve B cells. (B) In lupusprone mice, DCs and MФs are defective in the production of IL-6 and sCD40L, allowing both autoreactive and naïve B cells to produce Ig in response to TLR stimulation.
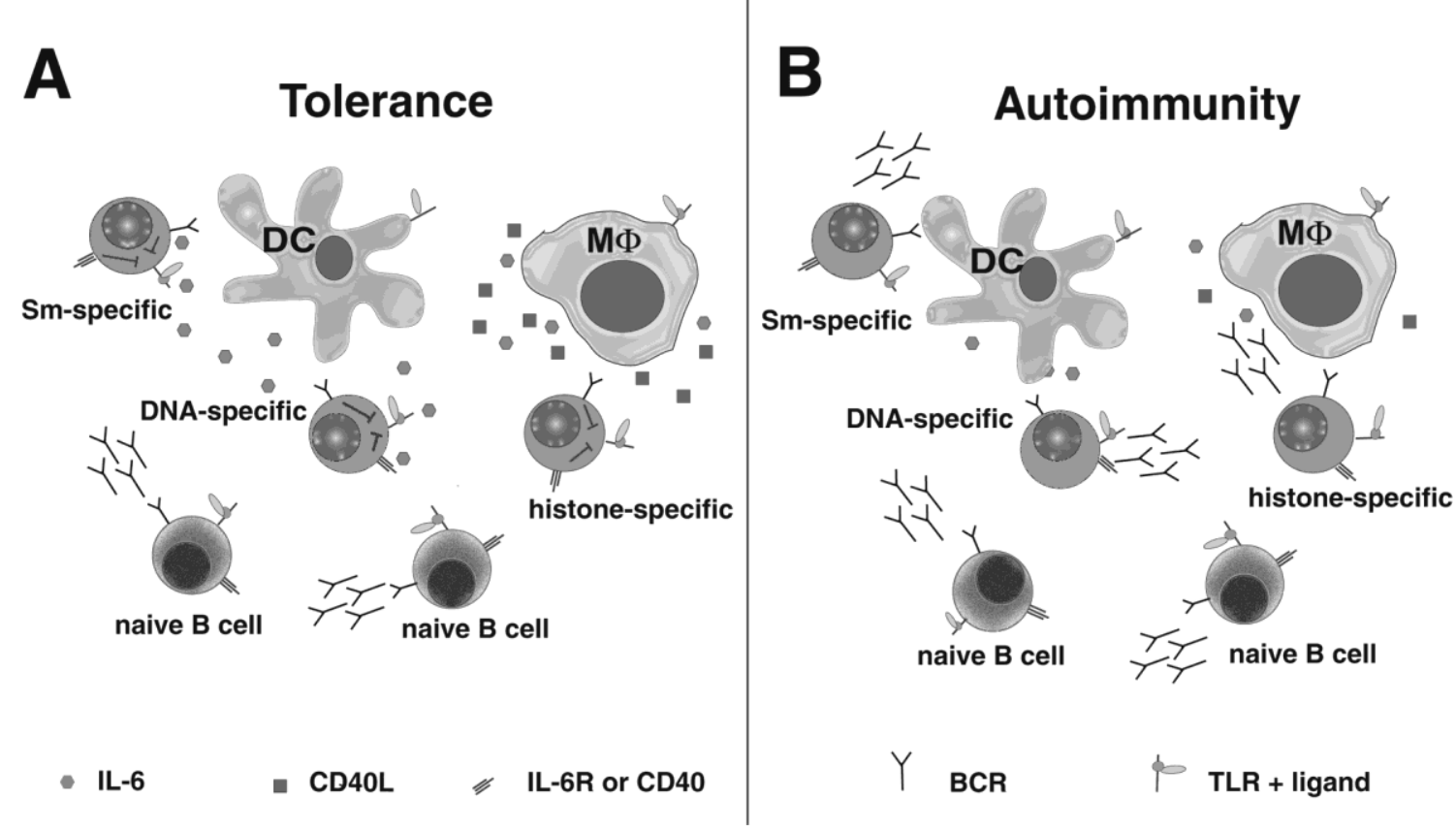


\section{CHAPTER II}

Tolerogenic ERK signaling prevents differentiation of autoreactive B cells during innate immune responses 


\section{$\underline{2.1 \text { Abstract }}$}

Systemic lupus erythematosus (SLE) highlights the dangers of dysregulated B cells and the importance of initiating and maintaining tolerance. In addition to central deletion, receptor editing, peripheral deletion, receptor revision, anergy, and indifference, we have described a mechanism of B cell tolerance wherein dendritic cells (DCs) and macrophages (MФs) regulate chronically antigen-experienced B cells during innate immune responses. In part, DCs and MФs repress antigen-experienced B cells by releasing interleukin-6 (IL-6) and soluble CD40 ligand (sCD40L). This mechanism is selective in that IL-6 and sCD40L do not affect Ig secretion by naïve cells during innate immune responses. In this manuscript, we show that repression by IL-6 and SCD40L is mediated by ERK activation and distinctive subcellular localization. This elaborate mechanism allows differential regulation of naïve and antigen-experienced B cells, permitting vigorous immune responses in the absence of autoimmunity 


\section{$\underline{2.2}$ Introduction}

The innate immune system pioneers the response to pathogens, promoting an inflammatory response and activation of a variety of immune cells. B cell activation and immunoglobulin (Ig) secretion are crucial for an effective early response and efficient clearance of pathogens. A broad swath of B cell specificities is critical in combating an array of pathogens during both the innate and adaptive immune responses, but the threat of autoimmunity is inherent in this diversity. Breaches in B cell tolerance can result in autoimmune diseases such as systemic lupus erythematosus (SLE). Since innate immune responses are inherently non-specific, it seems that these responses must incorporate tolerance mechanisms that distinguish between naïve and chronically antigenexperienced B cells. We recently identified a tolerance mechanism that selectively represses Ig secretion by autoreactive B cells during innate immune responses. We find that chronically antigen-experienced B cells are maintained in an unresponsive state by dendritic cells and macrophages that secrete IL-6 and/or sCD40L in response to innate stimuli binding Toll-like receptors (TLRs). DC/M $\Phi$-mediated tolerance is reversible in vitro; removal of dendritic cells and macrophages allow previously unresponsive B cells to secrete Ig in response to TLR ligands. Treating de-repressed B cells with dendritic cells, macrophages, recombinant IL-6 (rIL-6) or recombinant soluble sCD40L (rsCD40L) restores the repressed phenotype. The repressive effect of IL-6 and sCD40L is limited to chronically antigen-experienced B cells and naïve B cells remain competent to secrete Ig (1-3). This suggests that chronic B cell receptor (BCR) ligation in vivo affects the outcome of IL-6 receptor (IL-6R) and CD40 signal transduction. In effect, these receptors are "reprogrammed." In similar situations, IFN- $\alpha \beta$ signaling and sCD40L, IL- 
4, and LPS reprogram the IL-6R and the BCR, respectively (4-9). Our finding that DCs and MФs selectively regulate autoreactive B cells provides a cellular explanation for the ability of the immune system to mount polyclonal responses to pathogens without promoting a break in tolerance.

The molecular basis for the selective repression of antigen-experienced B cells during innate immune responses remains unclear. However, others have shown that BCR signaling opposes TLR-induced Ig secretion by antigen-experienced B cells and that this repression is mediated by ERK activation. In this report, we show that inhibiting extracellular signal-regulated kinase (ERK) activation during rIL-6 or rsCD40L stimulation prevents their repression of LPS-induced Ig secretion. The repression mediated by IL-6 and sCD40L is targeted upstream of plasma cell transcription factors such as BLIMP-1 and XBP-1. Analysis of ERK phosphorylation showed that neither IL6 nor sCD40L drastically changed the levels of activated ERK. However, chronically antigen-experienced B cells maintained higher basal phosphorylation of ERK. Finally, we determined that the subcellular localization of activated ERK is differentially regulated in naïve versus antigen-experienced B cells. These findings reveal an additional layer of antigen-experienced B cell regulation by DCs/MФs during innate immune stimulation. Identifying the molecular basis of IL-6/sCD40L-mediated repression may afford unique opportunities for therapeutics that obviate the need for immunosuppression in B cell-mediated autoimmune diseases. 


\section{$\underline{\text { 2.3 Materials and Methods }}$}

\section{Mice}

$2-12 \mathrm{H} / \mathrm{V} \kappa 8 \mathrm{Tg}$ and $2-12 \mathrm{H} \mathrm{Tg}$ mice were created as previously described $(10,11) .2-12 \mathrm{H} /$ VК4 mice were created and provided by Stephen Clarke (manuscript in press). C57BL/6 mice were purchased from The Jackson Laboratory (Bar Harbor, ME). All mice were 8 to 16 weeks old at the time of analysis. Animals were maintained in an accredited animal facility at University of North Carolina (Chapel Hill, NC).

\section{Reagents}

Recombinant IL-6 (rIL-6) was purchased from BD Biosciences (San Diego, CA) and Peprotech (Rocky Hill, NJ). Recombinant soluble CD40L (rsCD40L) was from R\&D Systems (Minneapolis, MN). Fluorochrome- or biotin- labeled antibodies specific for CD9, CD19, CD3, CD11b, and CD11c were purchased from BD Biosciences. Antibodies specific for phospho-ERK and total ERK1/2 were purchased from Cell Signaling Technologies. Anti-BLIMP-1 was purchased from Novus Biologicals (Littleton, CO). Antibodies specific for XBP-1, lamin A, and beta-tubulin were obtained from Santa Cruz Biotechnology, Inc. (Santa Cruz, CA). Horseradish peroxidaseconjugated secondary antibodies for immunoblotting were purchased from Promega (anti-rabbit-HRP, Madison, WI) or Invitrogen (anti-mouse IgG1-HRP, Carlsbad, CA).

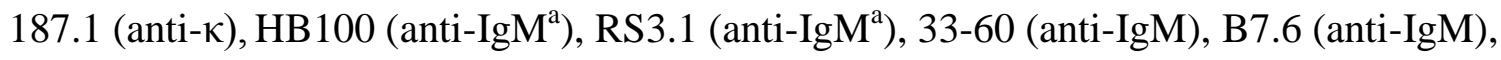
and 2.4G2 (CD16/32) were purified from hybridoma culture supernatant using Protein G Sepharose (GE Healthcare, Piscataway, NJ) or MEP HyperCel (BioSepra, Marlborough, MA) and biotinylated if necessary (Pierce, Rockford, IL). Sodium orthovanadate was 
obtained from Millipore (Billerica, MA). Protease inhibitors (phenylmethanesulfonyl fluoride (PMSF), dithiothreitol (DTT), aprotinin, alpha-1-antitrypsin, and leupeptin), and LPS from E. coli 055:B5 was purchased from Sigma (St. Louis, MO), and LPS from $E$. coli 0111:B4 was purchased from Invivogen (San Diego, CA). The MEK1 inhibitor U0126 was purchased from Calbiochem (San Diego, CA) and resuspended in dimethyl sulfoxide (DMSO, Sigma).

\section{B cell purification}

Splenic B cells were isolated by negative selection (StemCell Technologies, Vancouver, Canada). B cells were $90-95 \%$ pure (with fewer than $10 \%$ dendritic cells and macrophages), as determined by flow cytometry. Marginal zone (MZ) B cells were depleted from C57BL/6 splenocytes by supplementing the EasySep antibody mixture with biotinylated anti-CD9.

\section{LPS stimulation}

Purified B cells ( 1 x 10\% /per well) were cultured in the presence or absence of Sigma LPS (30ug/mL) for four days. Optimal amounts of rIL-6 (20 ng/mL), rsCD40L (25-75 $\mathrm{ng} / \mathrm{mL})$, and U0126 $(0.5 \mu \mathrm{M})$ were added at the initiation of the cultures. Cell-free culture supernatants were harvested and $\operatorname{IgM} / \kappa$ or total $\operatorname{IgM}$ secretion was measured by ELISA. 


\section{ELISA}

$\operatorname{IgM} / \kappa$ from $2-12 \mathrm{H} / \mathrm{V} \kappa 8$ and $2-12 \mathrm{H} / \mathrm{V} \kappa 4 \mathrm{~B}$ cell culture supernatants was captured with rat anti-mouse $\kappa(187.1)$ and detected with anti-Ig $\mathrm{M}^{\mathrm{a}}$-biotin (HB100-biotin), and streptavidin-alkaline phosphatase (Sigma) as described (11). Total IgM from C57B1/6 B cell culture supernatants was captured with rat anti-mouse IgM (33-60) and detected with rat anti-mouse IgM-biotin (B7.6) and streptavidin-alkaline phosphatase. $\operatorname{IgM}^{\mathrm{a}}$ from 2$12 \mathrm{H}$ cell culture supernatants was captured with rat anti-mouse $\operatorname{IgM}^{\mathrm{a}}(\mathrm{RS} 3.1)$ and detected with anti-IgM ${ }^{\mathrm{a}}$-biotin (HB100-biotin) and streptavidin-alkaline phosphatase. The standard for all ELISAs consisted of purified mouse $\operatorname{IgM} / \kappa$ (TEPC 183, Sigma). Data were plotted as percent of control, which was calculated as the percent secretion relative to cultures of LPS-stimulated purified B cells.

\section{Flow cytometry}

Single-cell suspensions of splenocytes were prepared and red blood cells were lysed using TAC lysis solution (1 M Tris, $0.15 \mathrm{M}$ ammonium chloride, and 0.1 M EDTA). All staining was done in phosphate-buffered saline with 2\% Fetal Clone II (Hyclone, Logan, UT). Fc receptors were blocked with anti-CD16/32 (2.4G2) for 5 min at room temperature. Surface markers were stained for 30 minutes at $4^{\circ} \mathrm{C}$ in the dark. Cells were analyzed at the University of North Carolina Flow Cytometry Facility (Chapel Hill, NC) using a Cyan flow cytometer (Dako, Carpinteria, CA). Data were analyzed using Summit software (Dako). All data represent cells that fell within the lymphocyte gate determined by forward and side scatter. One to $5 \times 10^{5}$ cells per sample were analyzed. 


\section{Real-time PCR}

Total RNA was extracted from 1-2 x $10^{6}$ B cells using TRIZOL (Invitrogen) as recommended by the manufacturer. cDNA was prepared with random hexamers and MMLV reverse transcriptase (Invitrogen, Carlsbad, CA) and analyzed in triplicate real-time PCR reactions. For relative quantification of message levels of Xbp-1, and secreted IgM, primers were designed using Primer3 (http://frodo.wi.mit.edu) and verified by dissociation analysis as well as gel electrophoresis and cloning and sequencing of PCR products (Table 2.1). Primers for Blimp-1 and 18s RNA have been described $((12,13)$. ABsolute $^{\text {TM }}$ QPCR SYBR ${ }^{\circledR}$ Green ROX (500nM) Mix (ABgene, Epsom, UK) was used with the following conditions: $2 \mathrm{~min}$ at $50^{\circ} \mathrm{C}, 10 \mathrm{~min}$ at $95^{\circ} \mathrm{C}$ for initial denaturing, followed by 40 cycles of $95{ }^{\circ} \mathrm{C}$ for $15 \mathrm{~s}$ and $62{ }^{\circ} \mathrm{C}$ for $1 \mathrm{~min}$, ending with a dissociation step of $95^{\circ} \mathrm{C}$ for $15 \mathrm{~s}, 62^{\circ} \mathrm{C}$ for $20 \mathrm{~s}$, and $97^{\circ} \mathrm{C}$ for $15 \mathrm{~s}$ to ensure that single products were amplified. Reactions were performed on an ABI PRISM 7000 Sequence Detection System (Applied Biosystems, Foster City, CA). Quantification of transcripts relative to 18s RNA transcripts was determined using the $\Delta \Delta C_{t}$ method (14) and expressed as foldinduction relative to 18 s RNA. 
Table 2.1 Real-time PCR primers and their sequences.

\begin{tabular}{|l|l|}
\hline Primer & Sequence \\
\hline Blimp-1 forward & 5'-TGTTGGATCTTCTCTTGGAAAA-3' \\
\hline Blimp-1 reverse & 5'-GTGTAAAGTAGACTGCCTTGA-3' \\
\hline Xbp-1 (total) forward & 5'-ACACGCTTGGGAATGGACAC'-3' \\
\hline Xbp-1 (total) reverse & 5'-CCATGGGAAGATGTTCTGGG-3' \\
\hline 18s forward & 5'-TCAAGAACGAAAGTCGGAGGTT-3' \\
\hline 18 s reverse & 5'-GGACATCTAAGGGCATCACAG-3' \\
\hline
\end{tabular}

Message levels of IL-6 receptor and GAPDH RNA were measured by real-time PCR using ABI On-Demand TaqMan primers and FAM-labeled probes (Applied Biosystems) according to the manufacturer's directions. Fluorescence was measured in triplicate realtime reactions by an ABI Prism 7000 SDS thermocycler and relative $C_{T}$ values were obtained from ABI Prism 7000 SDS software. Using the $\Delta \Delta \mathrm{C}_{\mathrm{T}}$ method, fold-induction values of IL-6 receptor were calculated relative to 18s RNA.

\section{Immunoblotting}

Purified splenic B cells were either lysed ex vivo or cultured with LPS alone $(30 \mu \mathrm{g} / \mathrm{mL})$ or in combination with rIL-6 (20 ng/mL) or rsCD40L (optimal dose of 25 or $75 \mathrm{ng} / \mathrm{mL}$ ) for three days. $3 \times 10^{6}$ cells were lysed in buffer containing $1 \%$ Igepal CA-630 (formerly known as NP-40, Sigma) and protease and phosphatase inhibitors (phenylmethanesulfonyl fluoride (PMSF), aprotinin, alpha-1-antitrypsin, leupeptin, and sodium orthovanadate). Whole-cell lysates were separated by SDS-PAGE, transferred to 
PVDF membrane in a semi-dry blotting apparatus, and immunoblotted for phospho-ERK and total ERK or BLIMP-1 and XBP-1. HRP-conjugated antibodies and ECL or ECL+ (GE Healthcare) were used to detect proteins.

\section{Nuclear and cytoplasmic extraction}

Purified splenic B cells were stimulated with LPS alone or in combination with rIL-6 or rsCD40L for 30 minutes. $15 \times 10^{6}$ cells were disrupted by hypotonic lysis and cytoplasmic and nuclear fractions were prepared as described previously $(15,16)$ with modifications. Protease and phosphatase inhibitors (described above, plus DTT) were added to both cytoplasmic and nuclear extract buffers. Protein concentrations were

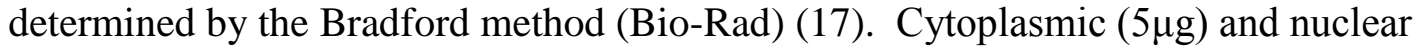
$(10 \mu \mathrm{g})$ extracts were separated by SDS-PAGE and immunoblotted as above with phospho-ERK, total ERK, lamin A, and beta-tubulin.

\section{Statistical analysis}

When comparing antibody secretion in treated and untreated cultures, the one-sample $t$ test was used. The unpaired $t$ test with Welch's correction was used to test for differences in antibody secretion between experimental groups. Statistical analyses were performed with GraphPad Prism (La Jolla, CA). 


\section{$\underline{2.4 \text { Results }}$}

IL-6 and SCD4OL regulate immunoglobulin secretion by antigen-experienced B cells

B cells expressing the 2-12H transgene recognize the self antigen Sm with a range of affinities depending on the light chain that is expressed. $2-12 \mathrm{H} / \mathrm{V} \kappa 8 \mathrm{~B}$ cells bind $\mathrm{Sm}$ with low affinity and fail to respond to LPS stimulation in ex vivo splenic cultures. These anergic B cells comprise an excellent system to study the regulation of B cells specific for a bona fide self-antigen. We previously reported that splenic $2-12 \mathrm{H} / \mathrm{V} \kappa 8 \mathrm{~B}$ cells are repressed by IL-6 and sCD40L produced by dendritic cells and macrophages in response to LPS $(2,3)$. In LPS-stimulated cultures of low-affinity $2-12 \mathrm{H} / \mathrm{V} \kappa 8$ B cells, rIL-6 and rsCD40L repressed $47 \%$ and $63 \%$ of Ig secretion, respectively (Figure 1A). This mechanism of regulation is not limited to low-affinity Sm-specific B cells. A range of BCR affinities for Sm is apparent in $2-12 \mathrm{H}$ mice due to their unrestricted light chain (10). LPS-induced Ig secretion from 2-12H B cells is repressed $34 \%$ by rIL-6 and $54 \%$ by rsCD40L (Figure 1B). 2-12H/Vк4 B cells bind Sm with a moderate affinity and are also susceptible to rIL-6- and rsCD40L-mediated repression (47\% and 35\%, respectively, Figure 1C). In contrast, naïve C57BL/6 B cells (Figure 1D) are not significantly repressed by these cytokines, indicating that continuous exposure to self-antigen in vivo is necessary to "reprogram" the IL-6 receptor and CD40 to repress Ig secretion. The level of IL-6 receptor (CD126) message is not significantly different between antigenexperienced and naïve B cells (Figure 1E), suggesting that the specificity of this repression is determined by a difference in signaling or downstream gene expression. In contrast, CD40 expression is increased on 2-12H/Vк8 B cells compared to C57BL/6 B cells (Figure 1F). However, it has been observed that CD40 is upregulated by BCR 
signaling and is increased on other anergic B cells that have presumably encountered antigen and are primed for $\mathrm{T}$ cell costimulation $(18,19)$. Therefore, higher expression of $\mathrm{CD} 40$ on $2-12 \mathrm{H} / \mathrm{V} \kappa 8 \mathrm{~B}$ cells could be due to antigen experience in vivo and this increase in expression, along with receptor reprogramming, could potentially explain the increased

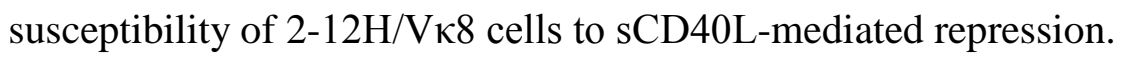

IL-6 and SCD4OL regulate transcription factors involved in plasma cell differentiation

Since IL-6 and sCD40L repress Ig secretion, we examined several transcription factors involved in plasma cell differentiation. BLIMP-1 is often referred to as the "master regulator" of plasma cell differentiation and immunoglobulin secretion (20). This transcription factor is responsible for extinguishing the mature B cell program by repressing Bcl-6, Pax5, and c-myc, while promoting immunoglobulin production and secretion through other factors such as XBP-1 (20-22). Levels of Blimp-1 message (Figure 2A) were reduced in 2-12/Vk8 cells treated with rIL-6 (by 49\%) or rsCD40L (by 47\%). We expected that BLIMP-1 protein levels would be similarly repressed. BLIMP1 was induced by LPS but reduced 50\% with rIL-6 treatment and $60 \%$ with rsCD40L treatment. XBP-1 also plays an important role in Ig secretion, coordinating the unfolded protein response $(21,23)$. Because XBP-1 is induced by BLIMP-1, we predicted that rIL-6 and rsCD40L would repress Xbp-1 message and proteins levels as well. Message levels of Xbp-1 in cultures treated with LPS and IL-6 decreased by 69\% (Figure 2A). rsCD40L repressed Xbp-1 message levels by 58\%. As expected, XBP-1 protein levels reflected the decrease in message levels. Both rIL-6 and rsCD40L repressed XBP-1 protein levels by more than $60 \%$. These results indicate that IL-6 and sCD40L exert their 
repressive influence upstream of key transcriptional factors that control Ig secretion by chronically antigen-experienced B cells.

\section{IL-6- and SCD4OL-mediated repression is rooted in tolerogenic ERK activation}

Antigen-experienced B cells are subject to chronic, tolerogenic BCR ligation in vivo and constant BCR occupancy is required to maintain anergy $(24,25)$. Others have shown that chronic ERK activation represses LPS- and CpG-induced Ig secretion in hen egg lysozyme-specific (HEL-Ig) B cells and that this repression can be reversed by pharmacologically inhibiting MEK $(26,27)$. Interestingly, both IL-6R and CD40 signaling induce ERK activation (28-30). Therefore, we predicted that IL-6- and sCD40L-mediated repression might be dependent on ERK activation resulting from IL6R or CD40 signaling. We cultured 2-12H/Vk8 B cells with LPS, rIL-6 or rsCD40L, and the MEK inhibitor, U0126. When ERK activation was inhibited in 2-12H/Vк8 B cells by U0126 treatment, rIL-6 and rsCD40L were no longer able to repress LPS-induced Ig secretion (Figure 3). These data indicate that rIL-6- and rsCD40L-mediated repression of antigen-experienced B cells is dependent on ERK activation.

\section{Basal ERK phosphorylation is increased in anti-Sm B cells}

Increases in basal ERK phosphorylation have been observed in antigenexperienced B cells versus their naïve counterparts $(31,32)$. This increase has been ascribed to chronic ligation of the BCR by self antigen. However, HEL-specific B cells have a very high affinity for HEL. Low-affinity interactions with self antigens such as Sm are more physiologically relevant, but it is not known whether these interactions 
result in increased basal ERK phosphorylation. We examined phosphorylation of ERK in freshly isolated naïve (C57BL/6) and antigen-experienced (2-12H/Vк8) B cells and observed that 2-12H/Vк8 B cells had higher basal ERK phosphorylation than C57BL/6 B cells (Figure 4). It is conceivable that in vivo, both high- and low-affinity self antigens confer tolerance by chronically ligating the BCR and activating ERK.

Unique subcellular localization of phosphorylated ERK in chronically antigenexperienced B cells

The ERK MAP kinase signaling cascade is quantitatively, temporally, and spatially regulated to prevent inappropriate activation or duration of receptor-mediated signaling (33). We have examined the amplitude and temporal patterns of ERK activation by rIL-6 and rsCD40L in naïve (C57BL/6) and antigen-experienced (212H/Vк8) B cells. rIL-6 and rsCD40L induced equivalent levels of ERK phosphorylation in naïve and antigen-experienced B cells within 30 minutes and duration of phosphorylation was not consistently longer in either C57BL/6 or $2-12 \mathrm{H} / \mathrm{V \kappa} 8 \mathrm{~B}$ cells (data not shown). Since the magnitude and duration of ERK phosphorylation did not appear to vary with chronic antigen experience, we theorized that the subcellular localization of phosphorylated ERK may be differentially regulated. ERK is anchored in the cytoplasm by its association with MEK, which contains a nuclear export signal (33). When ERK is activated, it generally dissociates from MEK and translocates to the nucleus, but certain stimuli can induce phosphorylation without translocation (33). We stimulated naïve and antigen-experienced B cells with LPS alone or in combination with rIL-6 or rsCD40L and isolated cytoplasmic and nuclear fractions. These extracts were 
immunoblotted for phosphorylated and total ERK as well as cytoplasmic and nuclear proteins. When we compared the distribution of phosphorylated ERK, differences between naïve and antigen-experienced B cells were evident. It was evident that in naïve B cells, LPS stimulation caused an increase in phosphorylated ERK in the nucleus regardless of rIL-6 and rsCD40L stimulation (Figure 5A). In contrast, when antigenexperienced B cells were stimulated with LPS, more phosphorylated ERK was evident in the nuclear fraction than in the cells stimulated with LPS combined with either rIL-6 or rsCD40L (Figure 5B). It appears that rIL-6 and rsCD40L alter the localization of activated ERK in antigen-experienced B cells compared to naïve B cells. However, it is unclear how phosphorylated ERK is anchored in the cytoplasm during IL-6- and sCD40L-mediated repression. 


\section{$\underline{\text { 2.5 Discussion }}$}

The innate immune system mounts a vigorous defense against pathogens by recognizing and responding to pathogen-associated molecular patterns (PAMPs) such as LPS and CpG. This polyclonal response is swift and robust, but inherently nonspecific. This lack of specificity is potentially hazardous because cells specific for autoantigens can trigger a bystander autoimmune response. For instance, there is a strong association between EBV seroconversion and SLE (34), and SLE patients have elevated Epstein-Barr virus loads in their blood (35). Additionally, during viral immunization of transgenic mice expressing a viral neo-self antigen, autoreactive B cells can evade negative selection in the periphery and become memory B cells (36). These autoreactive B cells can be reactivated by a second immunization; perhaps the presence of PAMPSs in subsequent infections would be sufficient to reactivate this pool of autoreactive B cells. A mechanism to discriminate between naïve and autoreactive B cells is crucial for a safe, effective immune response to pathogens. Ideally, the same polyclonal activators that activate naïve B cells would induce tolerance in autoreactive, antigen-experienced B cells to prevent unintentional autoimmunity. Our studies have shown that IL-6 and sCD40L, via ERK activation, repress LPS-induced Ig secretion in chronically antigen-experienced transgenic B cells but do not significantly affect naïve B cells. These soluble factors effectively repress B cells from several transgenic mouse models with low or

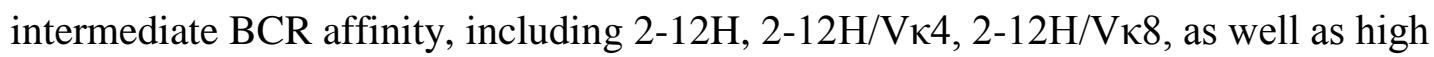
affinity B cells from HEL-Ig x sHEL mice $(2,3)$. This mechanism specifically targets chronically antigen-experienced B cells and therefore would be an extremely valuable tool in silencing autoreactive B cells in human diseases such as SLE. 
IL-6- and sCD40L-mediated repression of Ig secretion in chronically antigenexperienced B cells is mediated by ERK and reversible with pharmacological inhibitors of MEK. Basal ERK phosphorylation is increased in chronically antigen-experienced 212/Vk8 B cells compared to naïve C57BL/6 B cells, similar to antigen-experienced B cells from HEL-Ig x sHEL mice $(31,32)$. Since LPS, IL-6, and SCD40L all activate ERK, we initially predicted that ERK activation would be greater in repressible 212H/Vk8 cells compared to naïve C57BL/6 B cells. However, we observed no quantitative differences in the magnitude of ERK phosphorylation between antigenexperienced and naïve B cells. Additionally, ERK activation was sustained for similar periods of time in both antigen-experienced and naïve B cells. However, the effects of activated ERK can be regulated by its subcellular localization $(33,37,38)$. After ERK is activated, it translocates to the nucleus where it phosphorylates a variety of transcription factors $(39,40)$. ERK lacks any obvious nuclear export signals (NES) or nuclear localization signals (NLS). Therefore, it is reliant on MEK to either retain it in the cytoplasm or release it to allow nuclear translocation $(33,41,42)$. Other proteins such as kinase suppressor of Ras (KSR) can act as scaffolding that binds MEK and ERK and facilitates MAPK signaling (43). We observed reduced nuclear localization of activated ERK in repressed antigen-experienced B cells compared to naïve B cells. Therefore, it appears that the subcellular localization, rather than the magnitude and duration of ERK activation, may regulate the differential effects of IL-6- and SCD40L-mediated repression in naïve and chronically antigen-experienced B cells.

Although differential localization of activated ERK is coincident with IL6/sCD40L-mediated repression, additional studies are necessary to determine if exclusion 
of activated ERK from the nucleus is necessary or sufficient for repression of antigenexperienced B cells. To determine if the exclusion of activated ERK from the nucleus is sufficient for repression, antigen-experienced B cells could be retrovirally transduced with a MEK1/ERK2 fusion construct that is constitutively active and localized to the cytoplasm and assess if the B cells fail to secrete Ig (44). We predict expression of this construct would constitutively repress Ig secretion because ERK would be maintained in the cytoplasm. To determine if exclusion of activated ERK from the nucleus is necessary for repression, a second MEK1/ERK fusion protein could be transduced into antigenexperienced B cells. In this construct, the four leucines of the MEK1 NES are mutated to alanine, blocking nuclear export (LAMEK1/ERK2) (44). We predict expression of this construct would prevent IL-6/sCD40L-mediated repression of antigen-experienced B cells since activated ERK would be constitutively localized in the nucleus.

Activated ERK translocates to the nucleus and phosphorylates transcription factors such as ETS-1. ETS-1 negatively regulates BLIMP-1 and can repress plasma cell differentiation $(45,46)$. Decreased nuclear levels of activated ERK could result in decreased ETS-1 phosphorylation and impact its regulation of BLIMP-1 and plasma cell differentiation. Phosphorylation of ETS-1 and other ERK targets could be examined to determine the impact of decreased nuclear localization of activated ERK. These data could identify potential links between ERK and transcription factors such as BLIMP-1 and XBP-1. This information could provide additional targets for regulating antigenexperienced B cells during innate immune responses.

. The autoreactive B cells that wreak so much damage in SLE patients become dysregulated long before any clinical symptoms of disease. Genetic and environmental 
factors come together to unbalance all the normal mechanisms of tolerance. Other than immunosuppressive and B cell-depleting therapies, there is currently no way to silence these autoreactive cells while preserving the ability to mount a vigorous immune response against pathogens. Treatment options would be vastly improved if a therapy could incorporate a selective mechanism of tolerance such as the ERK-mediated repression described in this study. 


\section{$\underline{\text { 2.6 References }}$}

1. Seo, S. J., M. L. Fields, J. L. Buckler, A. J. Reed, L. Mandik-Nayak, S. A. Nish, R. J. Noelle, L. A. Turka, F. D. Finkelman, A. J. Caton, and J. Erikson. 2002. The impact of $\mathrm{T}$ helper and $\mathrm{T}$ regulatory cells on the regulation of anti-doublestranded DNA B cells. Immunity 16:535.

2. Kilmon, M. A., J. A. Rutan, S. H. Clarke, and B. J. Vilen. 2005. Low-affinity, Smith antigen-specific B cells are tolerized by dendritic cells and macrophages. $J$ Immunol 175:37.

3. Kilmon, M. A., N. J. Wagner, A. L. Garland, L. Lin, K. Aviszus, L. J. Wysocki, and B. J. Vilen. 2007. Macrophages prevent the differentiation of autoreactive B cells by secreting CD40 ligand and interleukin-6. Blood 110:1595.

4. Dye, J. R., A. Palvanov, B. Guo, and T. L. Rothstein. 2007. B Cell Receptor Cross-Talk: Exposure to Lipopolysaccharide Induces an Alternate Pathway for B Cell Receptor-Induced ERK Phosphorylation and NF-\{kappa\}B Activation. $J$ Immunol 179:229.

5. Guo, B., and T. L. Rothstein. 2005. B Cell Receptor (BCR) Cross-Talk: IL-4 Creates an Alternate Pathway for BCR-Induced ERK Activation That Is Phosphatidylinositol 3-Kinase Independent. J Immunol 174:5375.

6. Guo, B., D. Blair, T. C. Chiles, C. A. Lowell, and T. L. Rothstein. 2007. Cutting Edge: B cell receptor (BCR) cross-talk: the IL-4-induced alternate pathway for $\mathrm{BCR}$ signaling operates in parallel with the classical pathway, is sensitive to Rottlerin, and depends on Lyn. J Immunol 178:4726.

7. Mizuno, T., and T. L. Rothstein. 2005. B cell receptor (BCR) cross-talk: CD40 engagement creates an alternate pathway for BCR signaling that activates I kappa B kinase/I kappa B alpha/NF-kappa B without the need for PI3K and phospholipase C gamma. J Immunol 174:6062.

8. Mizuno, T., and T. L. Rothstein. 2005. B cell receptor (BCR) cross-talk: CD40 engagement enhances BCR-induced ERK activation. J Immunol 174:3369.

9. Mitani, Y., A. Takaoka, S. H. Kim, Y. Kato, T. Yokochi, N. Tanaka, and T. Taniguchi. 2001. Cross talk of the interferon-alpha/beta signalling complex with gp130 for effective interleukin-6 signalling. Genes Cells 6:631.

10. Santulli-Marotto, S., M. W. Retter, R. Gee, M. J. Mamula, and S. H. Clarke. 1998. Autoreactive B Cell Regulation: Peripheral Induction of Developmental Arrest by Lupus-Associated Autoantigens. Immunity 8:209. 
11. Borrero, M., and S. H. Clarke. 2002. Low-affinity anti-Smith antigen B cells are regulated by anergy as opposed to developmental arrest or differentiation to B-1. J Immunol 168:13.

12. Culton, D. A., B. P. O'Conner, K. L. Conway, R. Diz, J. Rutan, B. J. Vilen, and S. H. Clarke. 2006. Early preplasma cells define a tolerance checkpoint for autoreactive B cells. J Immunol 176:790.

13. Marino, J. H., P. Cook, and K. S. Miller. 2003. Accurate and statistically verified quantification of relative mRNA abundances using SYBR Green I and real-time RT-PCR. J Immunol Methods 283:291.

14. Livak, K. J., and T. D. Schmittgen. 2001. Analysis of relative gene expression data using real-time quantitative PCR and the 2(-Delta Delta C(T)) Method. Methods 25:402.

15. Dignam, J. D., R. M. Lebovitz, and R. G. Roeder. 1983. Accurate transcription initiation by RNA polymerase II in a soluble extract from isolated mammalian nuclei. Nucleic Acids Res 11:1475.

16. Liu, J. L., T. C. Chiles, R. J. Sen, and T. L. Rothstein. 1991. Inducible nuclear expression of NF-kappa B in primary B cells stimulated through the surface Ig receptor. J Immunol 146:1685.

17. Bradford, M. M. 1976. A rapid and sensitive method for the quantitation of microgram quantities of protein utilizing the principle of protein-dye binding. Anal Biochem 72:248.

18. Santulli-Marotto, S., Y. Qian, S. Ferguson, and S. H. Clarke. 2001. Anti-Sm B Cell Differentiation in Ig Transgenic MRL/Mp-lpr/lpr Mice: Altered Differentiation and an Accelerated Response. J Immunol 166:5292.

19. Ledbetter, J. A., G. Shu, M. Gallagher, and E. A. Clark. 1987. Augmentation of normal and malignant $\mathrm{B}$ cell proliferation by monoclonal antibody to the $\mathrm{B}$ cellspecific antigen BP50 (CDW40). J Immunol 138:788.

20. Shapiro-Shelef, M., K. I. Lin, L. J. McHeyzer-Williams, J. Liao, M. G. McHeyzer-Williams, and K. Calame. 2003. Blimp-1 is required for the formation of immunoglobulin secreting plasma cells and pre-plasma memory B cells. Immunity 19:607.

21. Shaffer, A. L., M. Shapiro-Shelef, N. N. Iwakoshi, A. H. Lee, S. B. Qian, H. Zhao, X. Yu, L. Yang, B. K. Tan, A. Rosenwald, E. M. Hurt, E. Petroulakis, N. Sonenberg, J. W. Yewdell, K. Calame, L. H. Glimcher, and L. M. Staudt. 2004. $\mathrm{XBP} 1$, downstream of Blimp-1, expands the secretory apparatus and other 
organelles, and increases protein synthesis in plasma cell differentiation. Immunity 21:81.

22. Shaffer, A. L., K. I. Lin, T. C. Kuo, X. Yu, E. M. Hurt, A. Rosenwald, J. M. Giltnane, L. Yang, H. Zhao, K. Calame, and L. M. Staudt. 2002. Blimp-1 orchestrates plasma cell differentiation by extinguishing the mature B cell gene expression program. Immunity 17:51.

23. Iwakoshi, N. N., A. H. Lee, P. Vallabhajosyula, K. L. Otipoby, K. Rajewsky, and L. H. Glimcher. 2003. Plasma cell differentiation and the unfolded protein response intersect at the transcription factor XBP-1. Nat Immunol 4:321.

24. Goodnow, C. C., R. Brink, and E. Adams. 1991. Breakdown of self-tolerance in anergic B lymphocytes. Nature 352:532.

25. Goodnow, C. C., J. Crosbie, H. Jorgensen, R. A. Brink, and A. Basten. 1989. Induction of self-tolerance in mature peripheral B lymphocytes. Nature 342:385.

26. Rui, L., C. G. Vinuesa, J. Blasioli, and C. C. Goodnow. 2003. Resistance to CpG DNA-induced autoimmunity through tolerogenic B cell antigen receptor ERK signaling. Nat Immunol 4:594.

27. Rui, L., J. I. Healy, J. Blasioli, and C. C. Goodnow. 2006. ERK signaling is a molecular switch integrating opposing inputs from $\mathrm{B}$ cell receptor and $\mathrm{T}$ cell cytokines to control TLR4-driven plasma cell differentiation. J Immunol 177:5337.

28. Li, Y., M. Baccam, S. Waters, J. Pessin, G. Bishop, and G. Koretzky. 1996. CD40 ligation results in protein kinase $\mathrm{C}$-independent activation of ERK and JNK in resting murine splenic B cells. J Immunol 157:1440.

29. Kashiwada, M., Y. Shirakata, J. I. Inoue, H. Nakano, K. Okazaki, K. Okumura, T. Yamamoto, H. Nagaoka, and T. Takemori. 1998. Tumor necrosis factor receptorassociated factor 6 (TRAF6) stimulates extracellular signal-regulated kinase (ERK) activity in CD40 signaling along a ras-independent pathway. $J$ Exp Med 187:237.

30. Ogata, A., D. Chauhan, G. Teoh, S. P. Treon, M. Urashima, R. L. Schlossman, and K. C. Anderson. 1997. IL-6 triggers cell growth via the Ras-dependent mitogen-activated protein kinase cascade. J Immunol 159:2212.

31. Healy, J. I., R. E. Dolmetsch, L. A. Timmerman, J. G. Cyster, M. L. Thomas, G. R. Crabtree, R. S. Lewis, and C. C. Goodnow. 1997. Different Nuclear Signals Are Activated by the B Cell Receptor during Positive Versus Negative Signaling. Immunity 6:419. 
32. Benschop, R. J., K. Aviszus, X. Zhang, T. Manser, J. C. Cambier, and L. J. Wysocki. 2001. Activation and anergy in bone marrow B cells of a novel immunoglobulin transgenic mouse that is both hapten specific and autoreactive. Immunity 14:33.

33. Ebisuya, M., K. Kondoh, and E. Nishida. 2005. The duration, magnitude and compartmentalization of ERK MAP kinase activity: mechanisms for providing signaling specificity. J Cell Sci 118:2997.

34. James, J. A., K. M. Kaufman, A. D. Farris, E. Taylor-Albert, T. J. Lehman, and J. B. Harley. 1997. An increased prevalence of Epstein-Barr virus infection in young patients suggests a possible etiology for systemic lupus erythematosus. J Clin Invest 100:3019.

35. Moon, U. Y., S. J. Park, S. T. Oh, W. U. Kim, S. H. Park, S. H. Lee, C. S. Cho, H. Y. Kim, W. K. Lee, and S. K. Lee. 2004. Patients with systemic lupus erythematosus have abnormally elevated Epstein-Barr virus load in blood. Arthritis Res Ther 6:R295.

36. Sundar, K., S. Jacques, P. Gottlieb, R. Villars, M. E. Benito, D. K. Taylor, and L. A. Spatz. 2004. Expression of the Epstein-Barr virus nuclear antigen-1 (EBNA-1) in the mouse can elicit the production of anti-dsDNA and anti-Sm antibodies. $J$ Autoimmun 23:127.

37. Adams, C. L., A. M. Grierson, A. M. Mowat, M. M. Harnett, and P. Garside. 2004. Differences in the kinetics, amplitude, and localization of ERK activation in anergy and priming revealed at the level of individual primary $\mathrm{T}$ cells by laser scanning cytometry. J Immunol 173:1579.

38. Shirakata, Y., K. Ishii, H. Yagita, K. Okumura, M. Taniguchi, and T. Takemori. 1999. Distinct subcellular localization and substrate specificity of extracellular signal-regulated kinase in B cells upon stimulation with IgM and CD40. $J$ Immunol 163:6589.

39. Goetze, S., X. P. Xi, Y. Kawano, H. Kawano, E. Fleck, W. A. Hsueh, and R. E. Law. 1999. TNF-alpha-induced migration of vascular smooth muscle cells is MAPK dependent. Hypertension 33:183.

40. Khurana, A., and C. S. Dey. 2002. Involvement of Elk-1 in L6E9 skeletal muscle differentiation. FEBS Lett 527:119.

41. Adachi, M., M. Fukuda, and E. Nishida. 2000. Nuclear export of MAP kinase (ERK) involves a MAP kinase kinase (MEK)-dependent active transport mechanism. J Cell Biol 148:849. 
42. Michaelis, M., T. Suhan, U. R. Michaelis, K. Beek, F. Rothweiler, L. Tausch, O. Werz, D. Eikel, M. Zornig, H. Nau, I. Fleming, H. W. Doerr, and J. Cinatl, Jr. 2006. Valproic acid induces extracellular signal-regulated kinase 1/2 activation and inhibits apoptosis in endothelial cells. Cell Death Differ 13:446.

43. Nguyen, A., W. R. Burack, J. L. Stock, R. Kortum, O. V. Chaika, M. Afkarian, W. J. Muller, K. M. Murphy, D. K. Morrison, R. E. Lewis, J. McNeish, and A. S. Shaw. 2002. Kinase suppressor of Ras (KSR) is a scaffold which facilitates mitogen-activated protein kinase activation in vivo. Mol Cell Biol 22:3035.

44. Luo, Y., and D. B. DeFranco. 2006. Opposing Roles for ERK1/2 in Neuronal Oxidative Toxicity: DISTINCT MECHANISMS OF ERK1/2 ACTION AT EARLY VERSUS LATE PHASES OF OXIDATIVE STRESS. J. Biol. Chem. 281:16436.

45. Wang, D., S. A. John, J. L. Clements, D. H. Percy, K. P. Barton, and L. A. Garrett-Sinha. 2005. Ets-1 deficiency leads to altered B cell differentiation, hyperresponsiveness to TLR9 and autoimmune disease. Int Immunol 17:1179.

46. John, S. A., J. L. Clements, L. M. Russell, and L. A. Garrett-Sinha. 2008. Ets-1 regulates plasma cell differentiation by interfering with the activity of the transcription factor Blimp-1. J Biol Chem 283:951. 


\section{$\underline{\text { 2.7 Figures }}$}

Figure 2.1. IL-6 and SCD40L selectively repress Ig secretion by chronically antigen-

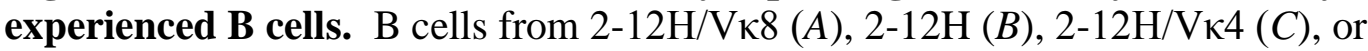
C57BL/6 $(D)$ mice were stimulated with LPS $(30 \mu \mathrm{g} / \mathrm{mL})$ or LPS combined with recombinant IL-6 (rIL-6, $20 \mathrm{ng} / \mathrm{mL}$ ) or recombinant soluble CD40L (rsCD40L, optimal dose of 25 or $75 \mathrm{ng} / \mathrm{mL})$ for four days. $\operatorname{IgM}^{\mathrm{a}} / \kappa(2-12 \mathrm{H} / \mathrm{V} \kappa 8$ and $2-12 \mathrm{H} / \mathrm{V \kappa} 4), \operatorname{IgM}^{\mathrm{a}}(2-$ $12 \mathrm{H})$, or total $\mathrm{IgM}(\mathrm{C} 57 \mathrm{Bl} / 6)$ were quantitated by ELISA. LPS-stimulated B cells (100\%) secreted 1.73-18.01 $\mu \mathrm{g} / \mathrm{ml} \operatorname{Ig}(A), 12.93-78.49 \mu \mathrm{g} / \mathrm{ml}(B), 7.06-26.75 \mu \mathrm{g} / \mathrm{ml}(C)$, and $16.81-27.50 \mu \mathrm{g} / \mathrm{ml}(D)$ from at least three experiments. (E), Ex vivo B cells were isolated from $\mathrm{C} 57 \mathrm{BL} / 6$ or $2-12 \mathrm{H} / \mathrm{V} \kappa 8$ mice, total RNA was extracted, reverse-transcribed to cDNA, and levels of IL-6 receptor (IL-6R) relative to GAPDH were determined by real-time PCR in 3 experiments. The levels of IL-6R were not significantly different between C57BL/6 and 2-12H/Vk8 B cells. $(F)$, Splenocytes from C57BL/6 or 2$12 \mathrm{H} / \mathrm{V} \kappa 8$ mice were stained for expression of CD19 and CD40 and analyzed by flow cytometry. The relative median fluorescence intensity (MFI) of CD40 on CD19+ cells is shown. The MFI of CD40 on 2-12H/Vк8 B cells was 1.6-fold higher than that of C57BL/6 B cells. Statistical analysis was performed using 1-sample $t$ test by comparing treated and untreated cultures $(A-D)$ or C57BL/6 and $2-12 \mathrm{H} / \mathrm{V} \kappa 8 \mathrm{~B}$ cells $(E-F)$. Data represent at least 3 experiments. Error bars represent plus or minus standard error (SEM). $(* * * P<0.001, * * P<0.01$.) 

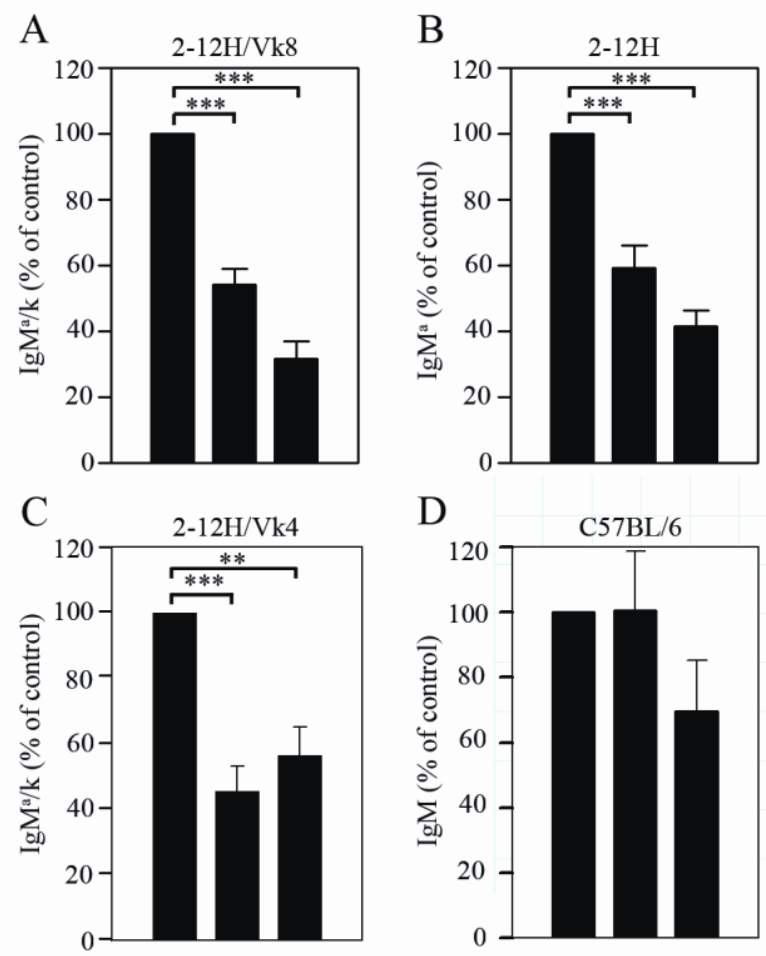

D
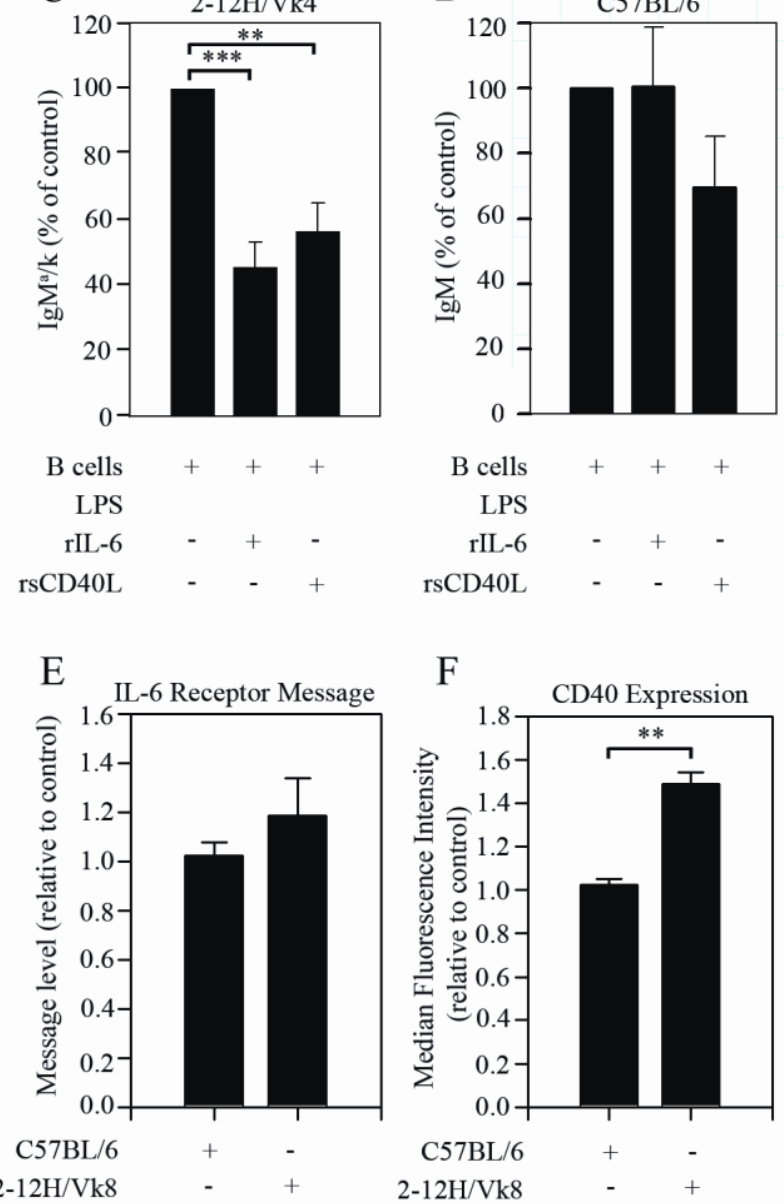
Figure 2.2. IL-6 and SCD40L treatment causes a decrease in levels of transcription factors involved in plasma cell differentiation. $(A-B), 2-12 \mathrm{H} / \mathrm{V} \kappa 8 \mathrm{~B}$ cells were stimulated for four days with LPS or LPS combined with rIL-6 or rsCD40L. Total RNA was extracted, reverse-transcribed to cDNA, and relative levels of Blimp-1 (A) and XBP$1(B)$ message were measured by real-time PCR in four experiments. Statistical analysis was performed using 1-sample $t$ test by comparing treated and untreated cultures $(A-B)$. Error bars represent plus or minus SEM. $\left(* * P<0.01,{ }^{*} P<0.05\right.$.) $(C-D), 2-12 \mathrm{H} / \mathrm{V} \kappa 8 \mathrm{~B}$ cells were cultured for three days with LPS or LPS combined with rIL-6 or rsCD40L. Lysates from $3 \times 10^{6}$ cells were separated by SDS-PAGE and immunoblotted for BLIMP-1 $(C)$ and XBP-1 $(D)$. The density of each band was quantitated with ImageJ and the fold changes were calculated. The data shown represent at least 3 experiments.

A
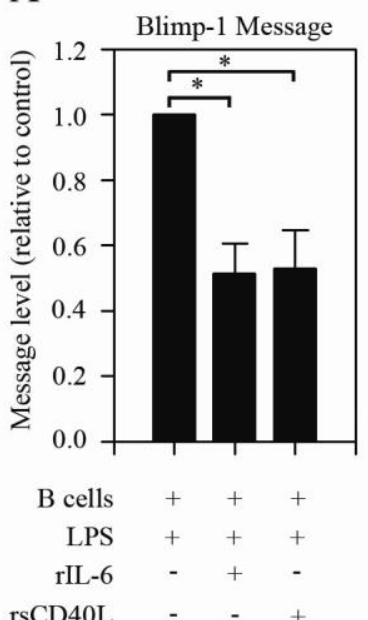

$\mathrm{C}$

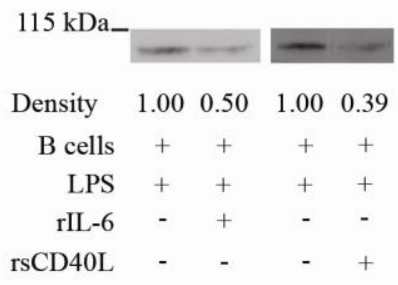

B

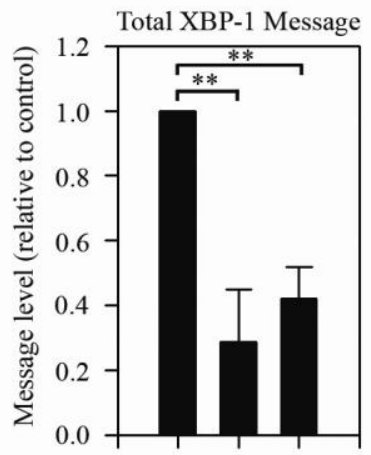

$\mathrm{B}$ cells $+\quad+\quad+$

LPS +++

rIL-6 - + $\mathrm{rSCD} 40 \mathrm{~L} \quad-\quad-\quad+$

D

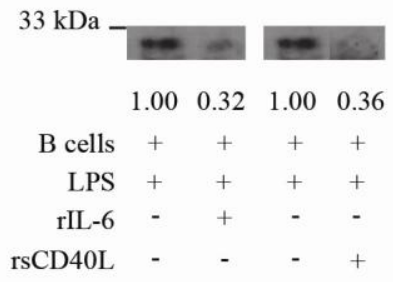


Figure 2.3. IL-6- and SCD40L-mediated repression is dependent on ERK activation. $2-12 \mathrm{H} / \mathrm{Vk} 8 \mathrm{~B}$ cells were stimulated for four days with LPS or LPS combined with rIL-6, rsCD40L, or U0126. IgM $/ \kappa$ levels in the culture supernatant were assayed by ELISA. LPS-stimulated B cells (100\%) secreted $1.35-18.01 \mu \mathrm{g} / \mathrm{ml}$ in at least four experiments. Statistical analysis was performed using 1-sample $t$ test by comparing treated and untreated cultures or Welch's unpaired $t$ test for comparisons between treatments. Data represent at least 3 experiments. Error bars represent plus or minus SEM. $(* * * P<0.001$, $* P<0.05$.)

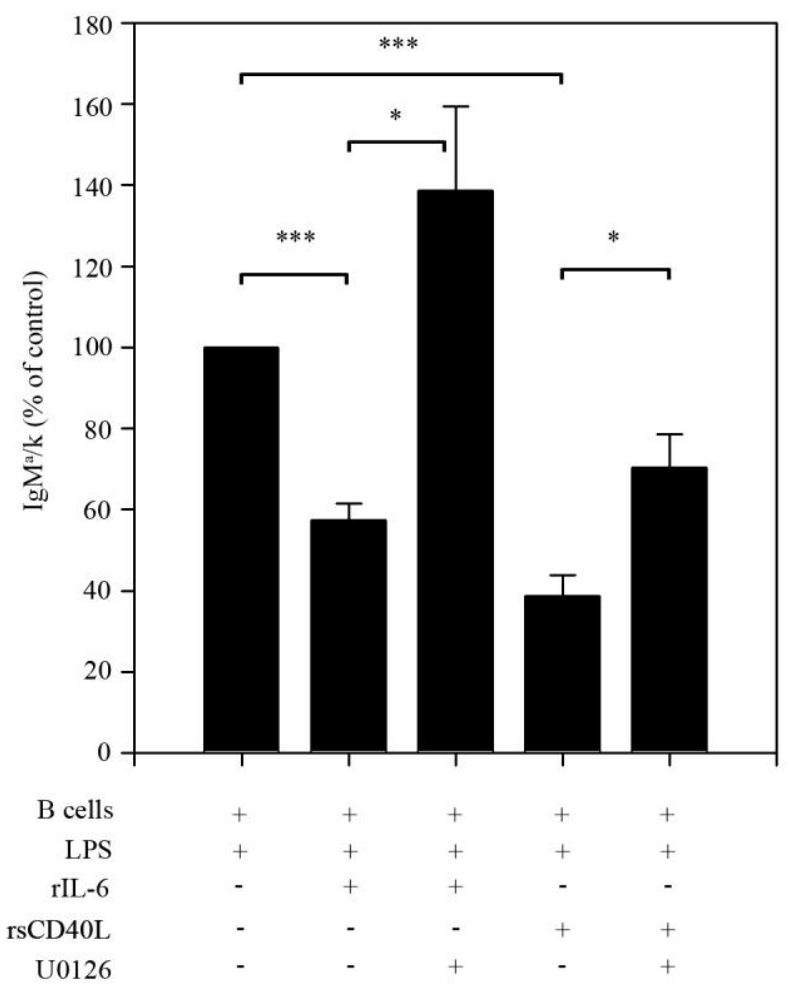


Figure 2.4. Chronically antigen-experienced $2-12 \mathrm{H} / \mathrm{V} \kappa 8 \mathrm{~B}$ cells exhibit higher basal phosphorylation of ERK than naïve C57BL/6 B cells. $3 \times 10^{6}$ purified ex vivo

C57BL/6 and 2-12H/Vк8 B cells were lysed and the proteins were separated on an SDSPAGE gel, transferred to PVDF membrane, and immunoblotted with antibodies specific for phosphorylated ERK and total ERK1/2. The density of each band was quantitated with ImageJ and the ratio of p-ERK2 to ERK 2 was calculated. The data shown represent at least three experiments.

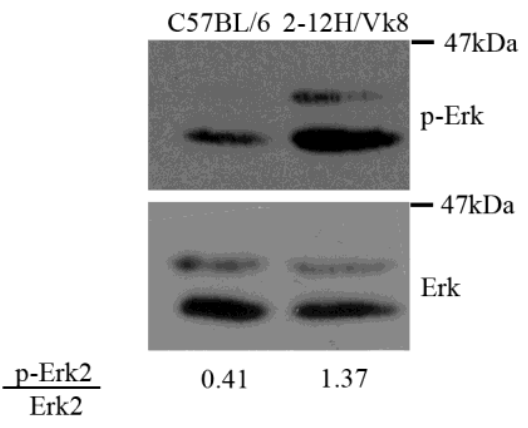


Figure 2.5. IL-6 and SCD40L alter the subcellular localization of activated ERK in chronically antigen-experienced B cells. $15 \times 10^{6}$ purified ex vivo C57BL/6 (A) and 2$12 \mathrm{H} / \mathrm{V} \kappa 8(B) \mathrm{B}$ cells were stimulated with LPS alone or in combination with rIL-6 and rsCD40L for 30 minutes. Cytoplasmic and nuclear fractions were isolated and the proteins were separated on an SDS-PAGE gel, transferred to PVDF membrane, and immunoblotted with antibodies specific for phosphorylated ERK, total ERK1/2, lamin A, and beta tubulin. The density of each band was quantitated with ImageJ and the ratio of p-ERK2 to ERK 2 was calculated. Phosphorylated ERK in the nuclear fractions of LPSstimulated $2-12 \mathrm{H} / \mathrm{V} \kappa 8 \mathrm{~B}$ cells decreased $38 \%$ and $62 \%$ with rIL-6 or rsCD40L treatment, compared with $27 \%$ and $0 \%$ reduction in the corresponding C57BL/6 samples. The data shown represent one experiment.

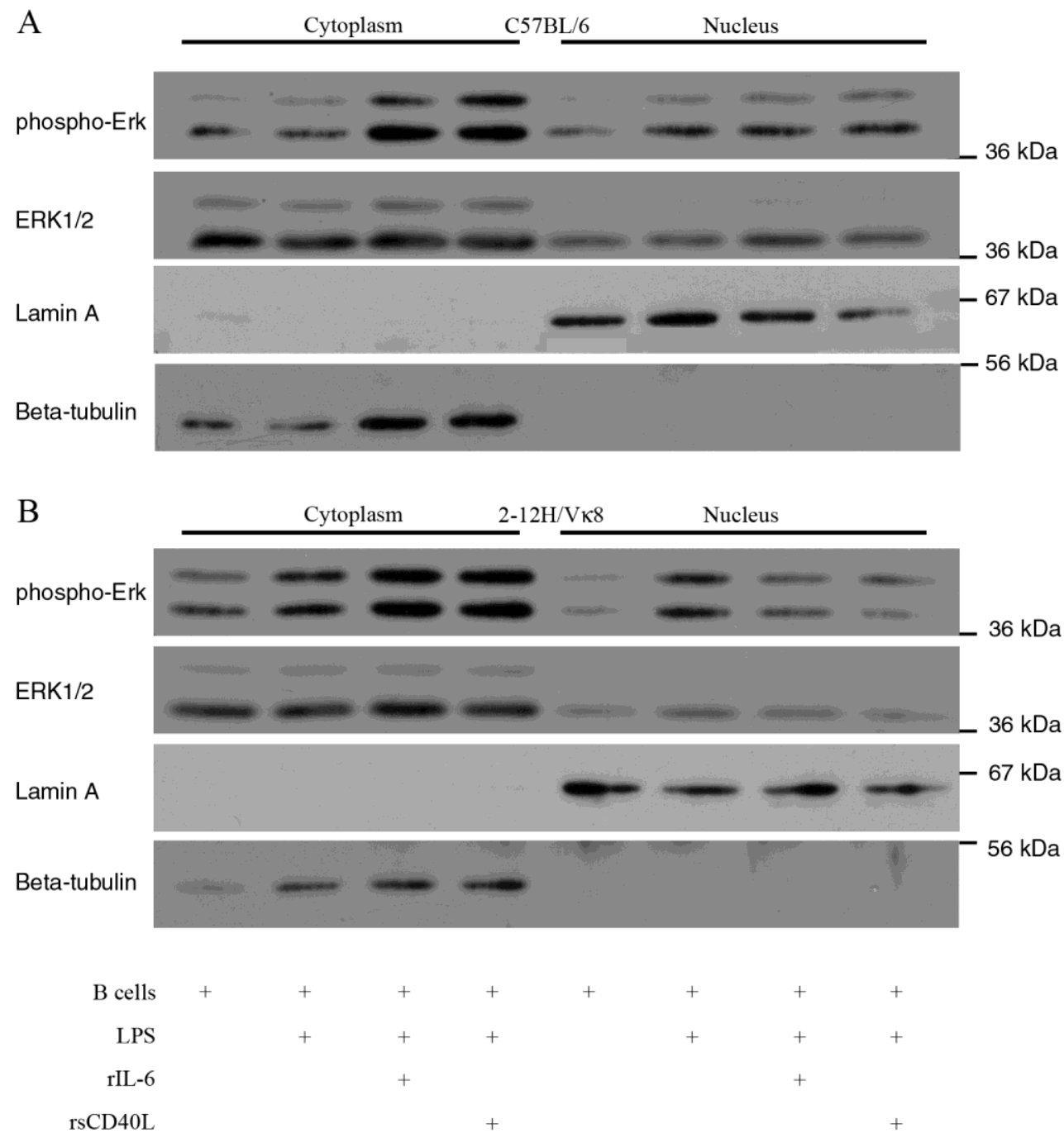


CHAPTER III

Discussion 
Innate immunity is an ancient defense system based upon the simplest principles of pattern recognition. The adaptive immune system mounts highly specific responses to clear and destroy pathogenic targets. The intersection of the innate and adaptive immune systems can lead to uncontrolled inflammation and autoimmunity if cross-reactive selfproteins are recognized by the innate immune system and in turn trigger a powerful adaptive immune response. In addition to tolerance mechanisms based upon antigen recognition by the $\mathrm{BCR}$ and $\mathrm{TCR}$, we are uncovering mechanisms that govern innate activation of naïve and antigen-experienced B cells.

The path to B cell activation and Ig secretion is lined with checkpoints to prevent inappropriate activation of autoreactive B cells. From the earliest stages of development, B cells are exquisitely sensitive to the affinities of their BCRs for autoantigens. In the bone marrow, central deletion and receptor editing remove autoreactive B cells from the repertoire before they exit to the periphery $(1,2)$. Additional trials await new B cell emigrants as they enter the spleen and are stimulated by a new set of autoantigens. Peripheral deletion, receptor revision, and follicular exclusion eliminate another swath of B cells with inappropriate specificities (3-5). Finally, low-affinity autoreactive B cells that bypass the previous mechanisms are held in an unresponsive state upon antigen ligation. Without appropriate costimulatory signals and cytokines to accompany antigen ligation, these B cells are suspended in an anergic state (6). Anergic B cells are unable to differentiate into plasma cells and secrete Ig, but may be receptive to BCR or TLR signals for proliferation or survival (7). Although these cells remain quiescent in normal individuals, the wide array of autoreactive specificities can be dangerous if tolerance is breached by a non-specific innate immune response. 
Autoreactive B cells risk polyclonal activation during infection and inflammatory responses. TLRs are sensors of pathogens, transducing signals from a variety of bacterial and viral ligands, including LPS, methylated CpG DNA, and ssRNA $(8,9)$. However, endogenous ligands such as non-methylated CpG DNA and ssRNA are present on the surface of apoptotic cells and by DCs and MФs (Carnathan et al, manuscript in preparation). These TLR ligands are often presented in the context of protein complexes such as snRNPs or opsonized apoptotic cells. Thus, rich arrays of autoantigens have the potential to co-ligate the BCR, TLRs, and Fc receptors, creating complex signals capable of activating autoreactive B cells $(10,11)$.

Receptor cross-talk allows ligands binding one receptor to regulate the response of another receptor to its ligand. In chronically antigen-experienced cells, it appears that the BCR, IL-6R, and CD40 form a tangled web of signaling pathways that alter the normal outcomes of TLR signaling. Elevated basal ERK phosphorylation is observed in

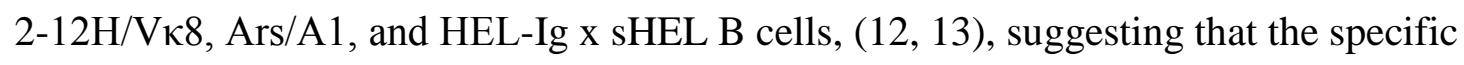
autoantigens are chronically signaling through the BCR. High-affinity antigens such as HEL are sufficient to repress LPS or CpG-induced Ig secretion via ERK activation (14, 15). However, the $2-12 \mathrm{H} / \mathrm{V} \kappa 8 \mathrm{BCR}$ has a low affinity for its specific antigen (Sm), and recombinant Sm is not able to repress LPS-induced Ig secretion in these B cells (data not shown). It is unknown whether a higher valency antigen, such as Sm in the context of small nuclear ribonucleic particles (snRNPs) or apoptotic cells, would be able to repress $2-12 \mathrm{H} / \mathrm{V} \kappa 8 \mathrm{~B}$ cells. Therefore, an additional mechanism is required to maintain tolerance in low-affinity B cells during innate immune stimulation. 
We have previously described a mechanism to regulate antigen-experienced B cells during a polyclonal, innate immune response $(16,17)$. DCs and MФs are activated by TLR ligands and secrete IL- 6 and sCD40L, preventing polyclonal activation of antigen-experienced B cells in the vicinity. However, naïve B cells are activated by TLR ligands and are not susceptible to DC/M $\Phi$-mediated repression. In contrast, IL-6 and sCD40L can promote activation and proliferation in naïve B cells, leading to plasma cell differentiation or germinal center formation $(18,19)$. DC/MФ-mediated tolerance appears to be a fail-safe mechanism of repressing antigen-experienced B cells during polyclonal stimulation.

IL-6R or CD40 signaling provides a source of tolerogenic ERK in low-affinity autoreactive B cells. These soluble factors repressIg production in antigen-experienced but not naïve B cells (Figure 1). It is interesting to consider if the differential effects of IL-6R and CD40 signaling in chronically antigen-experienced B cells is a consequence of the chronic BCR signaling these cells experience in vivo. We hypothesize that chronic BCR signaling reprograms the IL-6R and CD40 to produce "tolerogenic" instead of "activating" phosphorylated ERK. In naïve B cells or in autoreactive B cells that have overcome tolerance, such as 2-12H/MRL/lpr, IL-6 and sCD40L fail to repress Ig secretion (data not shown). The inability of IL-6 or sCD40L to repress autoimmune B cells may be due to differences in BCR signaling or a defect in crosstalk between the BCR and IL-6R and CD40. In these mice, we would expect that IL-6- and SCD40Linduced ERK would behave in an activating manner, similar to naïve B cells, rather than its tolerogenic actions in chronically antigen-experienced cells. Similarly, SLE patients exhibit elevated levels of IL-6 and sCD40L in their plasma, but these systemic levels are 
much lower than the amounts of IL-6 and sCD40L we find necessary to repress Ig secretion ex vivo $(20,21)$. Increased $\mathrm{SCD} 40 \mathrm{~L}$ actually correlates with anti-dsDNA titers and disease activity $(20,21)$. In these patients, increased IL-6 and sCD40L may actually enhance Ig secretion from B cells that have already bypassed all tolerance checkpoints.

With these data, we link two unlikely repressive factors to a molecular mechanism of anergy that is dependent on ERK activation. Both IL-6R and CD40 are capable of activating ERK in addition to other, more well-known signaling pathways (2225). When it was revealed that chronic BCR signaling induced tolerogenic ERK activation $(14,15)$, we predicted that IL-6R and CD40 signaling also resulted in tolerizing ERK activation. We established that IL-6- and SCD40L-mediated repression was dependent on ERK activation and only antigen-experienced B cells were susceptible to this mechanism. With this information, we commenced our search for the molecular basis of ERK-mediated repression.

Plasma cell differentiation and Ig secretion is a complex process involving many signaling molecules and transcription factors. Since we had previously determined that IL-6 and sCD40L repressed secreted Ig protein levels in 2-12H/Vк8 B cells, we systematically worked backwards from Ig secretion to transcription factor levels and the ERK/MAPK signaling pathway. We confirmed that IL-6 and SCD40L also repressed secreted Ig message levels (unpublished observations) and concluded that the target of repression was upstream of Ig transcription. We examined the message and protein levels of two key transcription factors in plasma cell differentiation, BLIMP-1 and XBP1. These transcription factors were significantly repressed by IL-6 and sCD40L, so we focused our search on the regulation of ERK itself. Like antigen-experienced B cells in 
other models, 2-12H/Vк8 B cells exhibit higher basal levels of phosphorylated ERK than C57BL/6 B cells. However, we did not find significant differences in the magnitude of IL-6/sCD40L-induced ERK activation in antigen-experienced versus naïve B cells. In both antigen-experienced and naïve B cells, IL-6/sCD40L augmented LPS-mediated ERK activation. Similar levels of phosphorylated ERK were observed in both cell types when we stimulated with IL-6 or sCD40L alone. Therefore, we did not observe significant differences in ERK activation by IL-6R and CD40 signaling, despite the increased expression of CD40 on 2-12H/Vк8 B cells. Next we examined the duration of IL-6/sCD40L-induced ERK activation in antigen-experienced and naïve B cells and did not observe consistent differences between the two cell types. Therefore, we eliminated differences in quantitative and temporal regulation of ERK activation as a mechanism for differential susceptibility of 2-12H/Vк8 and C57BL/6 B cells. Finally, we investigated the subcellular localization of phosphorylated ERK in antigen-experienced and naïve B cells stimulated with LPS and IL-6/sCD40L. Interestingly, we detected a reduction in phosphorylated ERK in nuclear fractions of antigen-experienced B cells stimulated with IL-6 or sCD40L. However, total protein levels of ERK1/2 were not visibly decreased. These results suggest that phosphorylated ERK is retained in the cytoplasm in repressed B cells, preventing its activation of downstream targets in the nucleus. After confirming these results, our next step would be to determine if nuclear exclusion of ERK is necessary and sufficient for repression and if IL-6/sCD40L-stimulation of antigenexperienced B cells reduces phosphorylation of ERK targets in the nucleus. Changes in phosphorylation of targets such as Ets-1 could impact its regulation of other transcription factors and repress plasma cell differentiation $(26,27)$. Identifying links between ERK 
and transcription factors such as BLIMP-1 and XBP-1 could further delineate the mechanism of IL-6/sCD40L-mediated repression.

In summary, DCs and MФs differentially regulate antigen-experienced and naïve B cell activation during innate immune responses by secreting IL-6 and sCD40L. IL-6 and SCD40L induce tolerogenic ERK, which is activated but unable to accumulate in the nucleus in antigen-experienced B cells. In contrast, these soluble factors induce activating ERK in naïve B cells, which is phosphorylated and accumulates in the nucleus, where it can potentially phosphorylate nuclear targets such as Ets-1. Knowing the molecular intricacies of ERK-mediated repression of autoreactive B cells could yield additional targets for therapies that selectively repress autoreactive B cells. New therapies could potentially reprogram the IL-6R or CD40, retain activated ERK in the cytoplasm, or prevent activation of transcription factors that link ERK signaling and BLIMP-1. Selective, targeted therapies like these would be a vast improvement over current options, which are limited to immunosuppression and global B cell depletion. Enhancing DC/MФ-mediated repression and restoring differential responses to IL6/sCD40L in autoreactive B cells in SLE patients and could reset the adaptive immune system and allow it to function safely and effectively during innate immune responses. 


\section{REFERENCES}

1. Nemazee, D. A., and K. Burki. 1989. Clonal deletion of B lymphocytes in a transgenic mouse bearing anti-MHC class I antibody genes. Nature 337:562.

2. Lang, J., M. Jackson, L. Teyton, A. Brunmark, K. Kane, and D. Nemazee. 1996. $B$ cells are exquisitely sensitive to central tolerance and receptor editing induced by ultralow affinity, membrane-bound antigen. $J$ Exp Med 184:1685.

3. Nemazee, D., and M. Weigert. 2000. Revising B Cell Receptors. J. Exp. Med. 191:1813.

4. Russell, D. M., Z. Dembic, G. Morahan, J. F. A. P. Miller, K. BUrki, and D. Nemazee. 1991. Peripheral deletion of self-reactive B cells. 354:308.

5. Cyster, J. G., S. B. Hartley, and C. C. Goodnow. 1994. Competition for follicular niches excludes self-reactive cells from the recirculating B-cell repertoire. Nature 371:389.

6. Goodnow, C. C., J. Crosbie, S. Adelstein, T. B. Lavoie, S. J. Smith-Gill, R. A. Brink, H. Pritchard-Briscoe, J. S. Wotherspoon, R. H. Loblay, K. Raphael, and et al. 1988. Altered immunoglobulin expression and functional silencing of selfreactive B lymphocytes in transgenic mice. Nature 334:676.

7. Cambier, J. C., S. B. Gauld, K. T. Merrell, and B. J. Vilen. 2007. B-cell anergy: from transgenic models to naturally occurring anergic B cells? Nat Rev Immunol 7:633.

8. Hornung, V., S. Rothenfusser, S. Britsch, A. Krug, B. Jahrsdorfer, T. Giese, S. Endres, and G. Hartmann. 2002. Quantitative expression of toll-like receptor 1-10 mRNA in cellular subsets of human peripheral blood mononuclear cells and sensitivity to CpG oligodeoxynucleotides. J Immunol 168:4531.

9. $\quad$ Ehlers, M., and J. V. Ravetch. 2007. Opposing effects of Toll-like receptor stimulation induce autoimmunity or tolerance. Trends in Immunology 28:74.

10. Leadbetter, E. A., I. R. Rifkin, A. M. Hohlbaum, B. C. Beaudette, M. J. Shlomchik, and A. Marshak-Rothstein. 2002. Chromatin-IgG complexes activate B cells by dual engagement of IgM and Toll-like receptors. Nature 416:603.

11. Lau, C. M., C. Broughton, A. S. Tabor, S. Akira, R. A. Flavell, M. J. Mamula, S. R. Christensen, M. J. Shlomchik, G. A. Viglianti, I. R. Rifkin, and A. MarshakRothstein. 2005. RNA-associated autoantigens activate B cells by combined B cell antigen receptor/Toll-like receptor 7 engagement. J. Exp. Med. 202:1171. 
12. Healy, J. I., R. E. Dolmetsch, L. A. Timmerman, J. G. Cyster, M. L. Thomas, G. R. Crabtree, R. S. Lewis, and C. C. Goodnow. 1997. Different Nuclear Signals Are Activated by the B Cell Receptor during Positive Versus Negative Signaling. Immunity 6:419.

13. Benschop, R. J., K. Aviszus, X. Zhang, T. Manser, J. C. Cambier, and L. J. Wysocki. 2001. Activation and anergy in bone marrow B cells of a novel immunoglobulin transgenic mouse that is both hapten specific and autoreactive. Immunity 14:33.

14. Rui, L., C. G. Vinuesa, J. Blasioli, and C. C. Goodnow. 2003. Resistance to CpG DNA-induced autoimmunity through tolerogenic B cell antigen receptor ERK signaling. Nat Immunol 4:594.

15. Rui, L., J. I. Healy, J. Blasioli, and C. C. Goodnow. 2006. ERK signaling is a molecular switch integrating opposing inputs from $\mathrm{B}$ cell receptor and $\mathrm{T}$ cell cytokines to control TLR4-driven plasma cell differentiation. J Immunol 177:5337.

16. Kilmon, M. A., J. A. Rutan, S. H. Clarke, and B. J. Vilen. 2005. Low-affinity, Smith antigen-specific B cells are tolerized by dendritic cells and macrophages. $J$ Immunol 175:37.

17. Kilmon, M. A., N. J. Wagner, A. L. Garland, L. Lin, K. Aviszus, L. J. Wysocki, and B. J. Vilen. 2007. Macrophages prevent the differentiation of autoreactive B cells by secreting CD40 ligand and interleukin-6. Blood 110:1595.

18. Jego, G., R. Bataille, and C. Pellat-Deceunynck. 2001. Interleukin-6 is a growth factor for nonmalignant human plasmablasts. Blood 97:1817.

19. Randall, T. D., A. W. Heath, L. Santos-Argumedo, M. C. Howard, I. L. Weissman, and F. E. Lund. 1998. Arrest of B lymphocyte terminal differentiation by CD40 signaling: mechanism for lack of antibody-secreting cells in germinal centers. Immunity 8:733.

20. Kato, K., E. Santana-Sahagun, L. Z. Rassenti, M. H. Weisman, N. Tamura, S. Kobayashi, H. Hashimoto, and T. J. Kipps. 1999. The soluble CD40 ligand sCD154 in systemic lupus erythematosus. J Clin Invest 104:947.

21. Davas, E. M., A. Tsirogianni, I. Kappou, D. Karamitsos, I. Economidou, and P. C. Dantis. 1999. Serum IL-6, TNFalpha, p55 srTNFalpha, p75srTNFalpha, srIL2alpha levels and disease activity in systemic lupus erythematosus. Clin Rheumatol 18:17. 
22. Heinrich, P. C., I. Behrmann, G. Muller-Newen, F. Schaper, and L. Graeve. 1998. Interleukin-6-type cytokine signalling through the gp130/Jak/STAT pathway.

Biochem J 334 ( Pt 2):297.

23. Daeipour, M., G. Kumar, M. C. Amaral, and A. E. Nel. 1993. Recombinant IL-6 activates p42 and p44 mitogen-activated protein kinases in the IL-6 responsive B cell line, AF-10. J Immunol 150:4743.

24. Kashiwada, M., Y. Shirakata, J. I. Inoue, H. Nakano, K. Okazaki, K. Okumura, T. Yamamoto, H. Nagaoka, and T. Takemori. 1998. Tumor necrosis factor receptorassociated factor 6 (TRAF6) stimulates extracellular signal-regulated kinase (ERK) activity in CD40 signaling along a ras-independent pathway. $J$ Exp Med 187:237.

25. Bishop, G. A., C. R. Moore, P. Xie, L. L. Stunz, and Z. J. Kraus. 2007. TRAF proteins in CD40 signaling. Adv Exp Med Biol 597:131.

26. Wang, D., S. A. John, J. L. Clements, D. H. Percy, K. P. Barton, and L. A. Garrett-Sinha. 2005. Ets-1 deficiency leads to altered B cell differentiation, hyperresponsiveness to TLR9 and autoimmune disease. Int Immunol 17:1179.

27. John, S. A., J. L. Clements, L. M. Russell, and L. A. Garrett-Sinha. 2008. Ets-1 regulates plasma cell differentiation by interfering with the activity of the transcription factor Blimp-1. J Biol Chem 283:951. 